\title{
Toward a Point-Of-Need Bioluminescence-Based Immunoassay Utilizing Complete Shelf-Stable Reagent
}

\author{
Mary P. Hall ${ }^{* 1}$, Virginia A. Kincaid*1, Emily A. Jost ${ }^{1}$, Thomas P. Smith ${ }^{2}$, Robin Hurst ${ }^{1}$, Stuart K. Forsyth ${ }^{1}$, \\ Connor Fitzgerald ${ }^{2}$, Val Ressler ${ }^{1}$, Kris Zimmermann ${ }^{1}$, Dan Lazar ${ }^{1}$, Monika G. Wood ${ }^{1}$, Keith V. Wood ${ }^{1}$, \\ Thomas A. Kirkland ${ }^{2}$, Lance P. Encell\# ${ }^{1}$, Thomas Machleidt ${ }^{1}$, and Melanie L. Dart\# ${ }^{1}$ \\ ${ }^{1}$ Promega Corporation, Madison, WI, USA \\ 2Promega Biosciences LLC, San Luis Obispo, CA, USA
}

\begin{abstract}
ELISAs are used extensively for the detection and quantification of biomolecules in clinical diagnostics as well as in basic research. Though broadly used, the inherent complexities of ELISAs preclude their utility for straightforward point-of-need testing, where speed and simplicity are essential. With this in mind, we developed a bioluminescence-based immunoassay format that provides a sensitive and simple method for detecting biomolecules in clinical samples. We utilized a ternary, splitNanoLuc luciferase complementation reporter consisting of two small peptides (11mer, 13mer) and a 17 kDa polypeptide, combined with a luminogenic substrate to create a complete, shelf-stable add-andread assay detection reagent. Directed evolution was used to optimize the reporter constituent sequences to impart chemical and thermal stability, as well as solubility, while formulation optimization was applied to stabilize an all-in-one reagent that can be reconstituted in aqueous buffers or sample matrices. The result of these efforts is a robust, first generation bioluminescence-based homogenous immunoassay reporter platform where all assay components can be configured into a stable lyophilized cake, supporting homogeneous, rapid, and sensitive one-step biomolecule quantification in complex human samples. This technology represents a promising alternative immunoassay format with significant potential to bring critical diagnostic molecular detection testing closer to the point-of-need.
\end{abstract}




\section{TABLE OF CONTENTS}

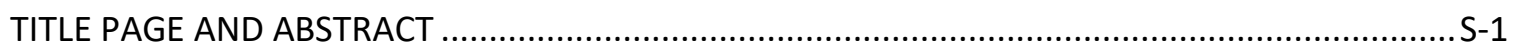

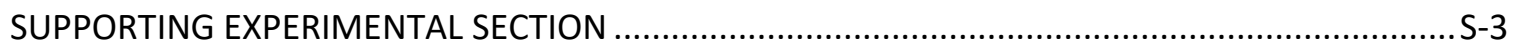

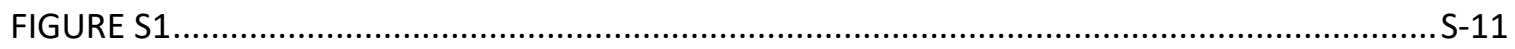

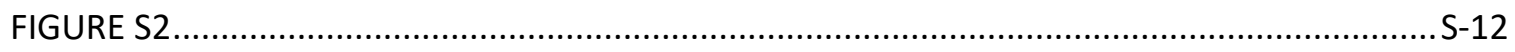

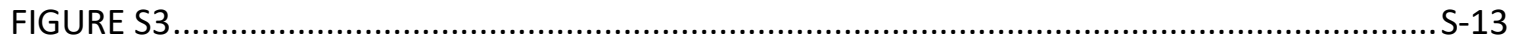

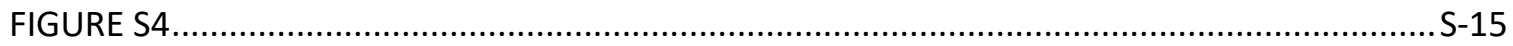

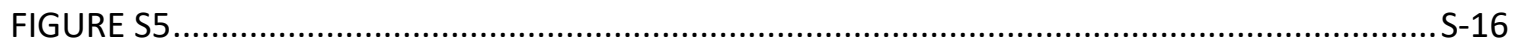

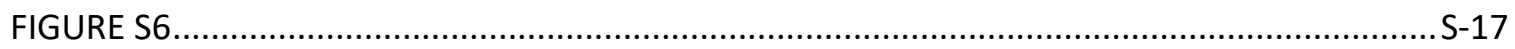

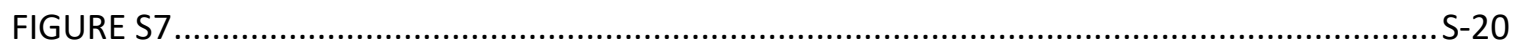

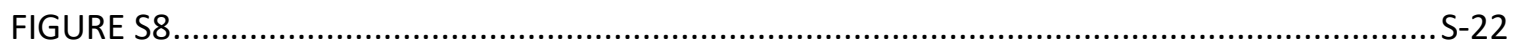

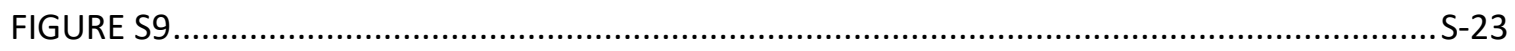

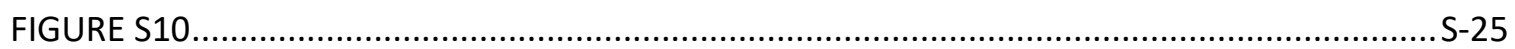

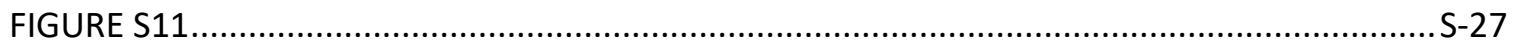

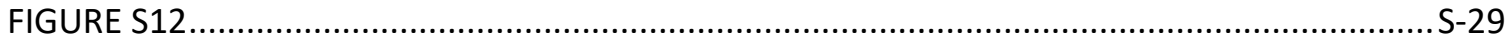

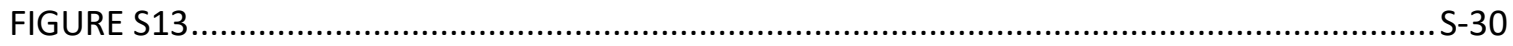

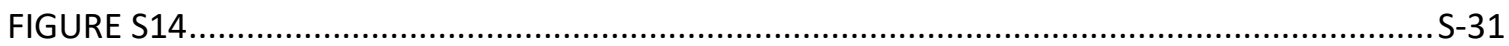

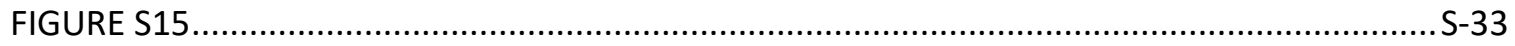




\section{SUPPORTING EXPERIMENTAL SECTION}

Computational 3D Structure Modeling. Molecular modeling, analyses, and visualizations were performed using Discovery Studio (Dassault Systèmes BIOVIA). We created a computational model of ternary Nluc representing NanoLuc (Protein Databank accession 5IBO ${ }^{1}$ ) with chain breaks after positions 146 and 157, separating $\beta$-strands $1-8$ ( $\mathrm{LgBiT}$ ) from $\beta$-strand 9 and $\beta$-strand 10 (HiBiT) $)^{2}$. Energy minimization was carried out using Discovery Studio protocol 'Calculate Mutation Energy (Stability)'3. For simplified visualization, the $\mathrm{N}$-terminal His-tag on the large subunit is hidden in the images presented here.

LgTrip Purification. Single colonies of E. coli KRX (Promega) harboring LgTrip variant plasmids were used to inoculate starter cultures that were grown for $18 \mathrm{~h}$ at $37{ }^{\circ} \mathrm{C}$ in LB broth + antibiotic. The overnight culture was diluted 1:100 into a flask containing $500 \mathrm{~mL}$ of LB $+0.1 \%$ Rhamnose $+0.15 \%$ Glucose + antibiotic and grown for $20 \mathrm{~h}$ at $25^{\circ} \mathrm{C}$ to induce overexpression. Cells were pelleted and re-suspended in a buffer containing Tris-buffered saline (TBS) with $0.2 \mathrm{mg} / \mathrm{mL}$ Lysozyme and $1 X$ Protease Inhibitor Cocktail (Promega). To prepare a lysate, the sample was subject to three freeze/thaw cycles. After the final thaw $0.001 \mathrm{U} / \mathrm{mL}$ RNAse-free DNase (RQ1, Promega) was added and the sample was incubated on ice for 30 min. The lysate was centrifuged, and the supernatant was loaded to a nickel-Sepharose column (HisTrap FF $1 \mathrm{ml}$; Cytiva) and then washed with 6-10 column volumes of Buffer A (20 mM imidazole, $50 \mathrm{mM}$ Tris pH 8.0, $500 \mathrm{mM} \mathrm{NaCl}, 0.005 \%$ IGEPAL, 10\% glycerol). Elution fractions (1 mL Buffer B: $500 \mathrm{mM}$ imidazole, $50 \mathrm{mM}$ Tris pH 8.0, $500 \mathrm{mM} \mathrm{NaCl}, 0.005 \%$ IGEPAL, 10\% glycerol) were collected, pooled, and dialyzed against $50 \mathrm{mM}$ Tris pH 7.5, $500 \mathrm{mM} \mathrm{NaCl}, 0.005 \%$ IGEPAL and 10\% glycerol. The final sample was diluted to $20 \mu \mathrm{M}$ and stored in a solution of $50 \%$ glycerol (for use in solution-based assays) or $10 \%$ sucrose (for use in lyophilized stock solutions) at $-20^{\circ} \mathrm{C}$.

LgBiT and LgTrip Stability. Purified LgBiT (Promega N401) or LgTrip variants were diluted to 2 nM in TBS $+0.01 \%$ BSA (TBSB) and then temperature challenged. At various time points samples were removed to ice. After the last time point, samples were equilibrated to ambient temperature and then $10 \mu \mathrm{L}$ of each was combined with $10 \mu \mathrm{L}$ of $10 \mu \mathrm{M}$ peptide comprising parental $\beta$-strand $9+\mathrm{HiBiT}$ (9-10 dipeptide) and incubated for 20 min at ambient temperature (final [LgBiT], [LgTrip] = $1 \mathrm{nM}$; final [9-10 dipeptide] = $5 \mu \mathrm{M}$ ). After incubation, $100 \mu \mathrm{L}$ of a solution of TBSB + Fz (diluted 250-fold from Promega N113) was added and samples were incubated for $5 \mathrm{~min}$ and then read on a GloMax ${ }^{\circledR}$ Discover luminometer. For the temperature gradient data shown in Figure S3e, $0.2 \mathrm{nM}$ LgBiT or LgTrip 3546 were used. After samples 
were incubated for $1 \mathrm{~h}$ at elevated temperature, $10 \mu \mathrm{L}$ of each sample was combined with $40 \mu \mathrm{L}$ of $2 \mu \mathrm{M}$ 9-10 dipeptide (final [LgBiT], [LgTrip] = 40 pM; final [9-10 dipeptide] = $1.6 \mu \mathrm{M}$ ), incubated for $20 \mathrm{~min}$ at ambient temperature, and read for luminescence after addition of a $50 \mu \mathrm{L}$ solution of TBSB $+\mathrm{Fz}$ (diluted 30-fold from Promega N205).

LgTrip Optimization. To improve thermal stability and increase the activity and expression of the LgTrip 2098 polypeptide we used directed evolution. First, we created a library of LgTrip 2098 mutants using Error Prone PCR (Diversify ${ }^{\mathrm{TM}}$ PCR Random Mutagenesis Kit, Takara Bio) which was cloned into E. coli KRX. Next, the library of LgTrip 2098 mutants was screened follows: E. coli clones containing LgTrip 2098 mutants were colony picked and grown overnight at $37^{\circ} \mathrm{C}$ in LB + antibiotic with shaking in 96 well plates. The next day cultures were diluted into LB induction media containing $0.1 \%$ Rhamnose + antibiotic and then grown for $3 \mathrm{~h}$ at $37^{\circ} \mathrm{C}$ to induce protein production. Cells were lysed (0.3X PLB (Promega) + 25 mM HEPES pH 7.5) and assayed with a solution of Nano-Glo ${ }^{\circledR}$ Luciferase Assay Reagent (Promega) supplemented with 500 nM 9-10 dipeptide. This concentration of 9-10 dipeptide was saturating and therefore enabled accurate screening for LgTrip 2098 mutants with improved expression, stability, or specific activity, and in a manner that was independent of the more complex, three component-based binding kinetics associated with the ternary system. We completed two rounds of directed evolution where each round consisted of screening of a random mutant library created by error prone PCR and then combining the most improved amino acid substitutions.

Binding Kinetics. LgTrip 2098 and LgTrip 3546 were diluted to 0.2 nM in TBSB + 0.01\% tergitol. A 3-fold dilution series of 9-10 dipeptide was prepared in TBSB $+0.01 \%$ tergitol starting at $1 \mu \mathrm{M}$. Next, $50 \mu \mathrm{L}$ of the 9-10 dipeptide titration was combined with $50 \mu \mathrm{L}$ of each LgTrip dilution and then incubated for 20 min at ambient temperature. Finally, $100 \mu \mathrm{L}$ of a detection reagent consisting of TBSB $+0.01 \%$ tergitol $+\mathrm{Fz}$ (diluted 250-fold from Promega N113) was added to samples. The plate was placed on an orbital shaker set to $600 \mathrm{rpm}$ for $30 \mathrm{~s}$ and then samples were read on a GloMax ${ }^{\circledR}$-Multi+ luminometer 5 min after substrate addition.

Impact of pH Exposure. A universal buffer consisting of $0.5 \%$ tergitol $(\mathrm{v} / \mathrm{v})$ and $25 \mathrm{mM}$ of each of the following buffers was prepared: Sodium Citrate, MES, PIPES, HEPES, TAPS. This buffer solution was divided into 12 aliquots and then either $\mathrm{NaOH}$ or $\mathrm{HCl}$ was added to each sample to produce a range of $\mathrm{pH}$ solutions. LgTrip 2098 and LgTrip 3546 were diluted to $2 \mathrm{nM}$ into each buffer of the pH series. Samples were 
incubated at ambient temperature for $24 \mathrm{~h}$. After incubation, samples were diluted 1:10 into $200 \mathrm{mM}$ HEPES pH 7.5. A solution of $500 \mathrm{nM}$ 9-10 dipeptide was prepared in $200 \mathrm{mM}$ HEPES buffer pH 7.5 and then $90 \mu \mathrm{L}$ was added to a 96 well plate. $10 \mu \mathrm{L}$ of each dilution was then added to the plate and samples were incubated for $20 \mathrm{~min}$ at ambient temperature. Next, $100 \mu \mathrm{L}$ of Fz (diluted 250-fold from Promega N113 into TBSB) was added and plates were read 2 min later.

Impact of $\mathrm{NaCl}$ Exposure. LgTrip 2098 and LgTrip 3546 were diluted to $0.2 \mu \mathrm{M}$ in TBSB. Two buffers were prepared: One consisting of $4.8 \mathrm{M} \mathrm{NaCl}+50 \mathrm{mM}$ Tris pH $7.5+0.01 \% \mathrm{BSA}$ and another consisting of 50 $\mathrm{mM}$ Tris $\mathrm{pH} 7.5+0.01 \% \mathrm{BSA}$. Two-fold serial dilutions were prepared starting with the $4.8 \mathrm{M} \mathrm{NaCl}$ using the no salt buffer as the diluent. The dilution series was transferred into 2 rows of a deep well plate. Next, the $0.2 \mu \mathrm{M}$ stocks of each protein were diluted to $2 \mathrm{nM}$ in the $\mathrm{NaCl}$ titration series. Samples were incubated for $24 \mathrm{~h}$ and then assayed with 9-10 dipeptide. First $90 \mu \mathrm{L}$ of a $500 \mathrm{nM}$ solution of 9-10 dipeptide in TBSB was added to white assay plates. Samples were diluted 1:10 in TBS and then $10 \mu \mathrm{L}$ of this solution was added to the 9-10 dipeptide and incubated for $20 \mathrm{~min}$. Next, $100 \mu \mathrm{L} \mathrm{of} \mathrm{Fz} \mathrm{(diluted} \mathrm{250-fold} \mathrm{from}$ Promega N113 in TBSB) was added to each sample. Plates were read 2 min after substrate dilution.

Strand 9 Optimization. Synthetic $\beta$-strand 9 peptide variants (Peptide 2.0 Inc.; blocked at termini) were designed and tested for activity and solubility. First, peptides were assessed for aqueous solubility by resuspension in $\mathrm{H}_{2} \mathrm{O}$ to $5 \mathrm{mM}$ according to their molecular weight. Samples that were not water soluble or precipitated after multiple freeze thaw cycles were eliminated from subsequent analysis. Next, watersoluble peptides were screened for affinity and maximum light output by titrating synthetic strand 9 peptides in the presence of saturating VS-HiBiT (HiBiT peptide with previously described beneficial ValSer linker $\left.{ }^{4-5}\right)(50 \mu \mathrm{M})$ and $0.1 \mathrm{nM}$ LgTrip 3546 in TBSB + 0.01\% tergitol. After a 20 min equilibration at ambient temperature, titrations were combined with an equal volume of a 250 -fold dilution of $\mathrm{Fz}$ (NanoGlo Luciferase Assay Substrate, Promega N113) in TBSB + 0.01\% tergitol. Luminescence was measured 10 min after Fz addition on a GloMax ${ }^{\circledR}$-Multi+ luminometer. For measuring VS-HiBiT affinity with strand 9 variants, the above protocol was repeated, but VS-HiBiT was titrated while holding strand 9 variants at saturating concentrations $(50 \mu \mathrm{M})$. For comparisons to binary Nluc (NanoBiT, i.e., LgBiT + VS-HiBiT) and full length Nluc, the following protocol was used. LgTrip 3546 (0.1 nM) was incubated with $50 \mu \mathrm{M}$ peptide 521 and $50 \mu \mathrm{M}$ VS-HiBiT for 20 min at ambient temperature in TBSB + 0.01\% tergitol. LgBiT (0.1 nM) was incubated with $200 \mathrm{nM}$ VS-HiBiT in the same buffer for $20 \mathrm{~min}$. Nluc (0.1 nM) was also incubated for 20 
$\min$ in the same buffer. Samples were read for luminescence $10 \mathrm{~min}$ after 1:1 addition of a 500-fold dilution of $\mathrm{Fz}$ (Promega N113) on a GloMax ${ }^{\circledR}$-Multi+ luminometer.

To assay $\beta$-strand 9 variants in the FRB/FKBP model, VS-HiBiT and strand 9 variants were genetically fused to the C-terminus of FRB and FKBP, respectively, using standard cloning techniques. This specific pairing of fusions was selected because it provided robust dynamic range for the assay when the parental peptide sequences were examined. We avoided strand 9 variants as $\mathrm{N}$-terminal fusion partners to minimize risk for artifacts in screening caused by expression differences ${ }^{6}$. Fusions were expressed in $E$. coli KRX and assayed as follows. Cultures were grown overnight at $37^{\circ} \mathrm{C}$ with shaking in LB with $100 \mu \mathrm{g} / \mathrm{mL}$ ampicillin. To induce protein expression, cells were diluted $1: 10$ in LB $+0.15 \%$ Glucose $+0.1 \%$ Rhamnose $+100 \mu \mathrm{g} / \mathrm{mL}$ ampicillin and grown for $20 \mathrm{~h}$ at $25^{\circ} \mathrm{C}$. Lysates were generated by diluting cells into Passive Lysis Buffer (Promega). Lysates of FKBP-strand 9 variants were combined with FRB-VS-HiBiT at a final dilution of 1:100 for each construct. Samples were incubated for $30 \mathrm{~min}$ at ambient temperature in the presence or absence of $30 \mathrm{nM}$ rapamycin and then combined 1:1 (v/v) with Nano-Glo Luciferase Assay Buffer (Promega N112) containing a 100-fold dilution of Fz (Promega N113). After a 5 min equilibration at ambient temperature, luminescence was measured on a GloMax ${ }^{\circledR}$-Multi+ luminometer.

Purification of HaloTag ${ }^{\oplus}$ Fusions to Peptide 521 and VS-HiBiT. $50 \mathrm{~mL}$ starter cultures of E. coli KRX harboring pFN29A-based T7 Flexi vectors (Promega) containing peptide 521 or VS-HiBiT were grown overnight at $37^{\circ} \mathrm{C}$ in LB media containing $100 \mu \mathrm{g} / \mathrm{mL}$ ampicillin. Cultures were diluted 1:100 into $500 \mathrm{~mL}$ fresh LB media containing ampicillin, $0.15 \%$ Glucose, and $0.2 \%$ Rhamnose. Cultures were grown for $24 \mathrm{~h}$ at $25{ }^{\circ} \mathrm{C}$. Cells were pelleted by centrifugation $(10,000 \mathrm{rpm})$ for $30 \mathrm{~min}$ at $4{ }^{\circ} \mathrm{C}$ and re-suspended in $50 \mathrm{~mL}$ PBS. $1 \mathrm{~mL}$ Protease Inhibitor Cocktail (Promega), $0.5 \mathrm{~mL}$ RQ1 DNase (Promega), and $0.5 \mathrm{~mL}$ of $10 \mathrm{mg} / \mathrm{mL}$ Lysozyme (Sigma) were added, and the cell suspension was incubated on ice with mild agitation for $1 \mathrm{~h}$. Cells were lysed by three freeze thaws and subsequently centrifuged at $10,000 \mathrm{rpm}$ for $30 \mathrm{~min}$ at $4{ }^{\circ} \mathrm{C}$. Supernatant was collected and HaloTag-VS-HiBiT was purified using batch methodology with Ni Sepharose 6Fast Flow (GE) using the manufacturer's recommended protocol. HaloTag-peptide 521 was purified using FPLC HisTrap FF $5 \mathrm{ml}$ columns (Cytiva). Protein was eluted using $500 \mathrm{mM}$ imidazole, dialyzed in PBS, and characterized to be $>95 \%$ pure using SDS-PAGE. Proteins were stored in PBS $+50 \%$ glycerol at $-20^{\circ} \mathrm{C}$.

Antibody Labeling. The following antibody pairs were used for model systems: 1) Mouse anti-human IL-6 monoclonal antibody (mAb) clones 5IL6 and 505E 9 A12 A3 (Thermo Fisher); 2) Mouse anti-human cardiac troponin I mAb clones 16A11 and 1H11L19 (Invitrogen); and 3) Mouse anti-human IL-1beta mAb clones 
508A 4A2 and 508A 7G8 (Thermo Fisher). Labeling of the antibodies with the HaloTag-peptide fusions was performed as previously described ${ }^{7}$ but with modifications. Antibodies were buffer exchanged $2 X$ into 10 $\mathrm{mM}$ sodium bicarbonate buffer ( $\mathrm{pH}$ 8.5) using Zeba spin desalting columns (Thermo Fisher). Antibodies were then incubated with $200 \mu \mathrm{M}$ amine reactive HaloTag Succinimidyl Ester (04) Ligand (Promega) for $2 \mathrm{~h}$ with orbital shaking $(1,000 \mathrm{rpm})$ at $22^{\circ} \mathrm{C}$. Unreacted ligand was removed with two passes through Zeba spin columns in PBS. Antibodies were then incubated with $30 \mu \mathrm{M}$ of the HaloTag-peptide 521 or HaloTag-VS-HiBiT fusion protein overnight with shaking at $4{ }^{\circ} \mathrm{C}$. Characterization of antibody labeling was carried out using native PAGE. Prior to gel analysis the reactions were run over HaloLink Resin (Promega) to remove excess HaloTag fusion. However, as the native PAGE image indicates this clean up step was not $100 \%$ efficient.

Purification of TNF $\alpha$ Fusion to VS-HiBiT. A $50 \mathrm{~mL}$ starter culture of E. coli T7 Shuffle (NEB) harboring a pF4Ag-based T7 Flexi vector (Promega) containing 6His-TNFa-15GS-VS-HiBiT was grown overnight in LB media containing $100 \mu \mathrm{g} / \mathrm{mL}$ ampicillin at $37^{\circ} \mathrm{C}$ (note TNF = soluble $17 \mathrm{kDa}$ sequence; $15 \mathrm{GS}=$ SSSGGGGSGGGSSGG). The culture was diluted 1:100 into $500 \mathrm{~mL}$ fresh LB media containing ampicillin and grown at $37^{\circ} \mathrm{C}$ until reaching a density of $\mathrm{OD} 600=0.6$, at which time a final concentration of $1 \mathrm{mM}$ IPTG was added. The culture was grown overnight at $25^{\circ} \mathrm{C}$ and then cells were harvested by centrifugation (10,000 rpm, $30 \mathrm{~min}$ ) and re-suspended in $50 \mathrm{~mL}$ TBS, $1 \mathrm{~mL}$ protease inhibitor cocktail (Promega), $0.5 \mathrm{~mL}$ RQ1 DNase (Promega), and $1 \mathrm{~mL}$ of $10 \mathrm{mg} / \mathrm{mL}$ lysozyme (Sigma). After incubating on ice with mild agitation for $1 \mathrm{~h}$ cells were lysed by three freeze-thaw cycles from $-80^{\circ} \mathrm{C}$ to $37^{\circ} \mathrm{C}$ and subsequently centrifuged at $10,000 \mathrm{rpm}$ for $30 \mathrm{~min}$ at $4{ }^{\circ} \mathrm{C}$. Supernatant was collected and protein was purified using Ni Sepharose 6 Fast Flow resin (GE), following the manufacturer's recommended protocol. Protein was eluted using step-wise imidazole addition (100-500 mM), dialyzed in TBS, and characterized by SDS-PAGE to be $>95 \%$ pure. Proteins were stored in TBS $+50 \%$ glycerol at $-20{ }^{\circ} \mathrm{C}$.

Purification of Protein G Fusion to Peptide 521. A $50 \mathrm{~mL}$ starter culture of E. coli KRX (Promega) harboring the pF1A-based T7 Flexi vector (Promega) containing Peptide 521-15GS-Protein G was grown overnight in LB media containing $100 \mu \mathrm{g} / \mathrm{mL}$ ampicillin at $37^{\circ} \mathrm{C}$ (15GS = SSSGGGGSGGGSSGG). The culture was diluted 1:100 into $500 \mathrm{~mL}$ fresh LB media containing $100 \mu \mathrm{g} / \mathrm{mL}$ ampicillin, $0.15 \%$ glucose, and $0.1 \%$ rhamnose. The culture was grown for $20 \mathrm{~h}$ at $25^{\circ} \mathrm{C}$. Cells were harvested $(10,000 \mathrm{rpm}, 30 \mathrm{~min})$ and re-suspended in $50 \mathrm{~mL}$ TBS. $1 \mathrm{~mL}$ protease inhibitor cocktail (Promega), $0.5 \mathrm{~mL}$ RQ1 DNase 
(Promega), and $1 \mathrm{~mL}$ of $10 \mathrm{mg} / \mathrm{mL}$ lysozyme (Sigma) were added, and the cell suspension was incubated on ice with mild agitation for $1 \mathrm{~h}$. Cells were lysed by three freeze-thaw cycles $\left(-80^{\circ} \mathrm{C}\right.$ to $\left.37^{\circ} \mathrm{C}\right)$ and subsequently centrifuged at $10,000 \mathrm{rpm}$ for $30 \mathrm{~min}$ at $4{ }^{\circ} \mathrm{C}$. The supernatant was collected and protein purified using a HisTrap FF column (GE) on an ÄKTAprime plus FPLC (GE), following the manufacturer's recommended protocol. Protein was eluted by imidazole using a gradient up to $500 \mathrm{mM}$, dialyzed in TBS, and characterized using SDS-PAGE to be $>95 \%$ pure. Protein was stored in TBS $+50 \%$ glycerol at $-20{ }^{\circ} \mathrm{C}$.

IL-1beta, Remicade, and Cardiac Troponin I Solution-based Immunoassays. Protocols were the same as described for the solution-based IL-6 immunoassay in the Experimental Section of the main text but we used the following reagent concentrations: $100 \mathrm{ng} / \mathrm{mL}$ VS-HiBiT labeled anti-IL-1beta clone 508A 7G8, 100 $\mathrm{ng} / \mathrm{mL}$ peptide 521 labeled anti-IL-1beta clone 508A 4A2, $2 \mathrm{ng} / \mathrm{mL}$ peptide 521 labeled anti-troponin clone 1H11L19, $50 \mathrm{ng} / \mathrm{mL}$ VS-HiBiT labeled anti-troponin clone 16A11, $10 \mathrm{ng} / \mathrm{mL}$ Protein G-peptide 521 fusion protein, and $10 \mathrm{ng} / \mathrm{mL}$ TNF $\alpha$-VS-HiBiT protein fusion. Recombinant human IL-1beta was sourced from PeproTech, Cardiac Troponin I from Fitzgerald, and Remicade from Myonex.

Invitrogen Human IL-6 Instant ELISA. Assay performed per manufacturer's supplied protocol.

Human subjects. Control plasma samples from pre-pandemic timepoints donated from healthy adults (n $=21)$ and serum from individuals who tested PCR+ for SARS-CoV-2 $(n=35)$ and experienced a clinically severe infection requiring hospitalization were commercially sourced from Boca Biolistics. An additional $\mathrm{n}=7$ SARS-CoV-2 serum samples were obtained from local participants who previously had a PCR+ test result and hospitalization due to SARS-CoV-2 but were in the convalescent stage. This study was approved by the Human Subjects Board of Promega Corporation and informed consent for participation in the study for purposes of clinical research was signed by the individuals.

Complete IL-6 Immunoassay Lyophilization in Glass Vials and Characterization (additional details from main text). The $20 \mathrm{X}$ stock assay reagent solution contained the following: $2.5 \% \mathrm{w} / \mathrm{v}$ Pullulan, $5 \mathrm{mM} 6$-Aza2-thiothymine (ATT), $5 \mathrm{mM}$ ascorbic acid, $20 \mathrm{mM}$ HEPES (pH 8.0), $90 \mathrm{mM}$ Glycine, $20 \mathrm{mM}$ Histidine, 25 $\mathrm{mg} / \mathrm{mL}$ Sucrose, $0.01 \%$ Polysorbate $80,1.2 \mu \mathrm{g} / \mathrm{mL}$ VS-HiBiT labeled anti-IL-6 antibody (clone 505E 9 A12 A3), $0.6 \mu \mathrm{g} / \mathrm{mL}$ peptide 521 labeled anti-IL-6 antibody (clone 5IL6), $20 \mu \mathrm{M}$ LgTrip 3546, and $100 \mu \mathrm{M}$ Fz. All materials used to make the complete complex buffer were from Sigma. Testing of the buffer for 
background luminescence and compatibility with the IL- 6 assay was carried out using the same assay described for the solution-based IL-6 immunoassay. For lyophilization, double vented siliconized butyl rubber stoppers (West Pharmaceutical Services) were partially inserted into the vials prior to loading into the lyophilizer (Virtis Genesis 12EL) with shelves pre-set to $4{ }^{\circ} \mathrm{C}$. Product then underwent a freezing step with a shelf temperature of $-50^{\circ} \mathrm{C}$ for $2 \mathrm{~h}$. Upon evacuation of the system the lyophilization process was performed between shelf temperatures of $-25^{\circ} \mathrm{C}$ and $25{ }^{\circ} \mathrm{C}$ and pressures of 75 and 200 mTorr. The ice sublimation phase lasted $8 \mathrm{~h}$ and the bound water desorption phase lasted $16 \mathrm{~h}$. At the end of the lyophilization process, the vials were back filled with $\mathrm{N}_{2}$ and sealed with fully inserted stoppers at 600 Torr of pressure.

Complete IL-6 Immunoassay Lyophilization in 96-well Plates and Characterization. To evaluate the potential application of lyophilization for preservation of the entire ternary Nluc-based IL-6 immunoassay directly into a 96-well microtiter plates, formulations containing complete complex buffer (described above) with $0.12 \mu \mathrm{g} / \mathrm{mL}$ peptide 521 labeled anti-IL-6 antibody (clone 5IL6), $0.24 \mu \mathrm{g} / \mathrm{mL}$ VS-HiBiT labeled anti-IL-6 antibody (clone 505E A12 A3), $4 \mu \mathrm{M}$ LgTrip 3546, and $40 \mu \mathrm{M}$ Fz in EtOH was prepared creating the $4 \mathrm{X}$ stock solution. $25 \mu \mathrm{l}$ aliquots of $4 \mathrm{X}$ stock solution was dispensed into 96 -well microtiter plates (Costar 3912). Plates were loaded into the lyophilizer (Virtis Genesis 12EL) with shelves pre-chilled to $4{ }^{\circ} \mathrm{C}$. Product then underwent a freezing step with a shelf temperature of $-50^{\circ} \mathrm{C}$ for $2 \mathrm{~h}$ prior to condenser cooling. During the run, the condenser temperature ran between $-5^{\circ} \mathrm{C}$ and $-87^{\circ} \mathrm{C}$. After condenser cooling, the lyophilizer was evacuated and subsequently run at pressure set points of 75 and 200 mTorr. Sublimation took $\sim 7.5 \mathrm{~h}$, and desorption lasted $\sim 16 \mathrm{~h}$. Following lyophilization, the plates were back-filled with $\mathrm{N}_{2}$ and sealed with adhesive plate cover.

To characterize performance and stability, plates were stored at $-20^{\circ} \mathrm{C}$ or at ambient temperature and tested at various timepoints post lyophilization. $100 \mu \mathrm{L}$ of recombinant rhIL-6 (R\&D Systems) prepared in PBSB was added directly to the plates, incubated for $90 \mathrm{~min}$, and analyzed for total luminescence using a GloMax ${ }^{\circledR}$ Discover Luminometer (Promega).

Data Analysis. Immunoassay dose response titrations were fitted to a 4-parameter logistic regression equation with $1 / \mathrm{Y}^{2}$ weighting function (GraphPad Prism 8). Limit of detection (LOD) was calculated as $\mathrm{RLU}_{\text {blank }}+3 \times \mathrm{SD}_{\text {blank. }}$. Lower limit of quantification (LLOQ) was calculated as RLUblank $+3 \times \mathrm{SD}_{\text {blank. Upper }}$ limit of quantification (ULOQ) was calculated as $\mathrm{RLU}_{\text {[high analyte] }}+10 \times \mathrm{SD}_{\text {[high analyte] }}$. The resulting $\mathrm{RLU}$ values were then interpolated on the standard curve to estimate the concentrations. ELISA and Ternary Nluc 
data sampling serum and plasma samples from healthy, normal individuals and those with severe SARSCoV-2 infections were analyzed using the Bland-Altman method of comparison.

\section{SUPPORTING REFERENCES}

1. Lovell, S., Mehzabeen, N., Battaile, K.P., Wood, M.G., Encell, L.P., Wood, K.V., Univeristy of Kansas and Promega Corporation (2016), 1.95A resolution structure of NanoLuc luciferase doi: $10.2210 / p d b 5 \mid B O / p d b$.

2. Dixon, A. S.; Schwinn, M. K.; Hall, M. P.; Zimmerman, K.; Otto, P.; Lubben, T. H.; Butler, B. L.; Binkowski, B. F.; Machleidt, T.; Kirkland, T. A.; Wood, M. G.; Eggers, C. T.; Encell, L. P.; Wood, K. V., NanoLuc Complementation Reporter Optimized for Accurate Measurement of Protein Interactions in Cells. ACS Chem. Biol. 2016, 11 (2), 400-8.

3. Spassov, V. Z.; Yan, L., A pH-dependent computational approach to the effect of mutations on protein stability. J. Comput. Chem. 2016, 37 (29), 2573-87.

4. Schwinn, M. K.; Steffen, L. S.; Zimmerman, K.; Wood, K. V.; Machleidt, T., A Simple and Scalable Strategy for Analysis of Endogenous Protein Dynamics. Sci. Rep. 2020, 10 (1), 8953.

5. Boursier, M. E.; Levin, S.; Zimmerman, K.; Machleidt, T.; Hurst, R.; Butler, B. L.; Eggers, C. T.; Kirkland, T. A.; Wood, K. V.; Friedman Ohana, R., The luminescent HiBiT peptide enables selective quantitation of $\mathrm{G}$ protein-coupled receptor ligand engagement and internalization in living cells. J. Biol. Chem. 2020, 295 (15), 5124-5135.

6. Bivona, L.; Zou, Z.; Stutzman, N.; Sun, P. D., Influence of the second amino acid on recombinant protein expression. Protein Expr. Purif. 2010, 74 (2), 248-56.

7. Nath, N.; Flemming, R.; Godat, B.; Urh, M., Development of NanoLuc bridging immunoassay for detection of anti-drug antibodies. J. Immunol. Methods 2017, 450, 17-26. 


\section{Figure S1}

(a)

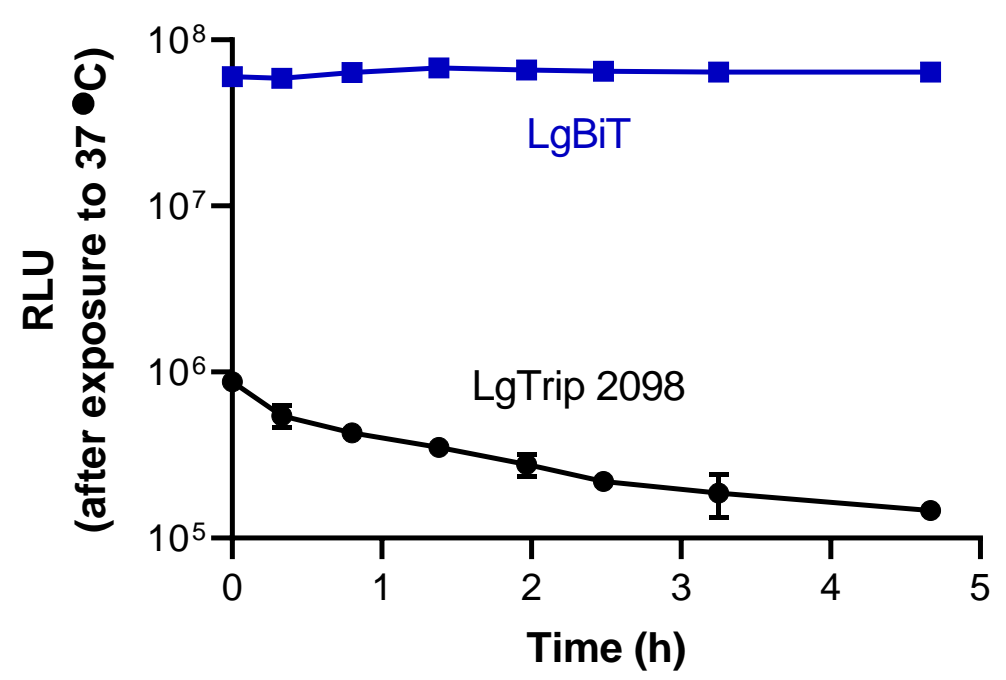

(b)

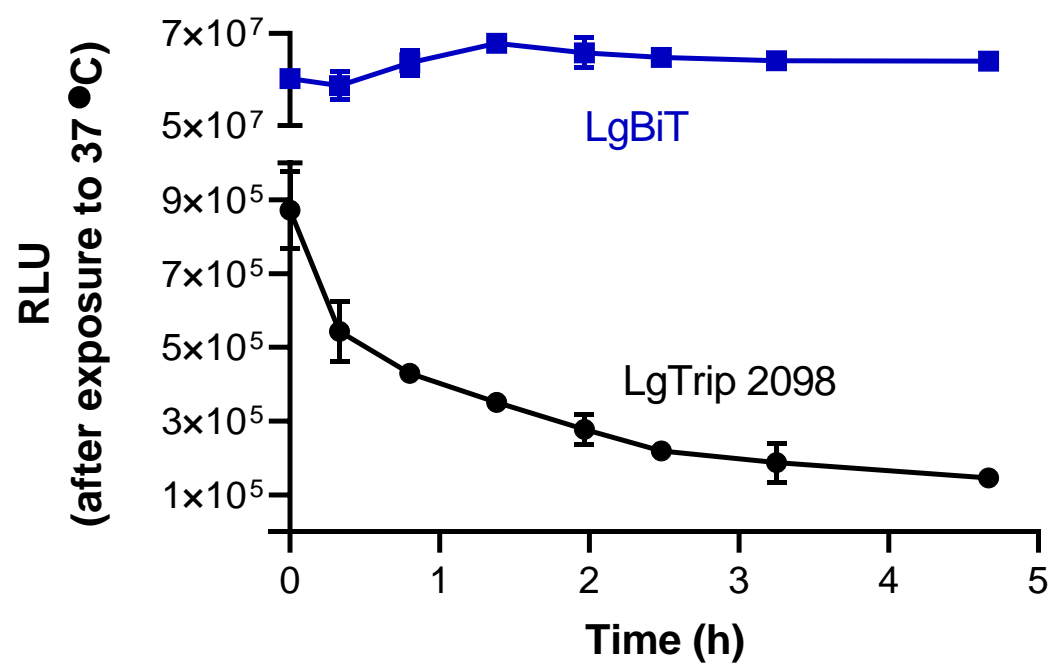

Figure S1. Signal strength and stability of LgBiT ( $\beta$-strands $1-9)$ and LgTrip 2098 ( $\beta$-strands $1-8)$. (a) Luminescence signal and stability for LgBiT and LgTrip 2098 after exposure to $37^{\circ} \mathrm{C}$ in TBSB. HiBiT (VSGWRLFKKIS) was the complementing peptide for LgBiT. 9-10 dipeptide (GSMLFRVTINSVSGWRLFKKIS) was the complementing peptide for LgTrip 2098. LgBiT is both significantly brighter and more stable compared to LgTrip 2098. Shown are mean RLU values (n $=4$ ) with variability expressed as SD. (b) Identical data from panel a but plotted on a linear, split $\mathrm{y}$-axis scale. LgBiT was stable for the duration of this experiment, while LgTrip 2098 lost half its activity within $1 \mathrm{~h}$. 


\section{Figure S2}

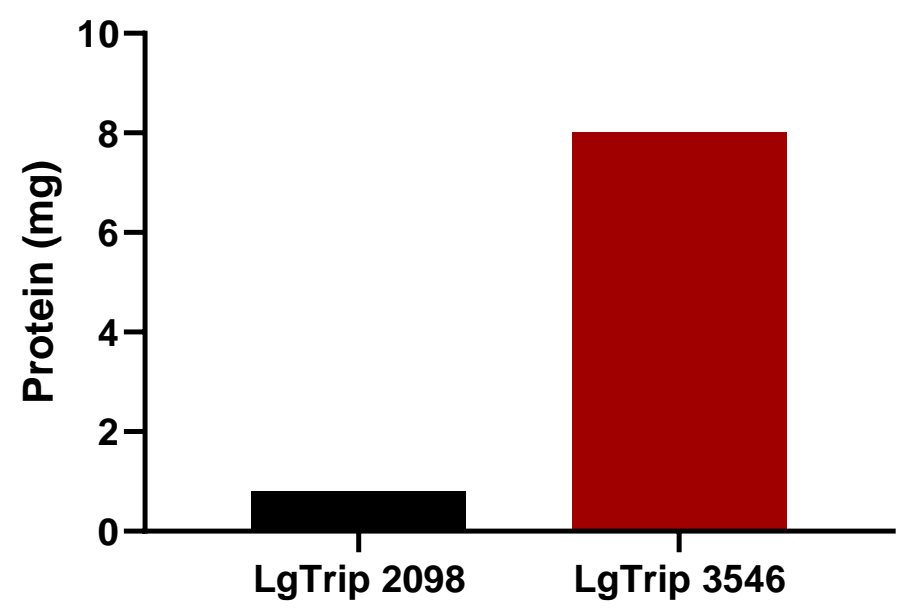

Figure S2. Yield of protein from $5 \mathrm{~g}$ of E. coli KRX cell paste for LgTrip 2098 or LgTrip 3546. 


\section{Figure S3}

(a)

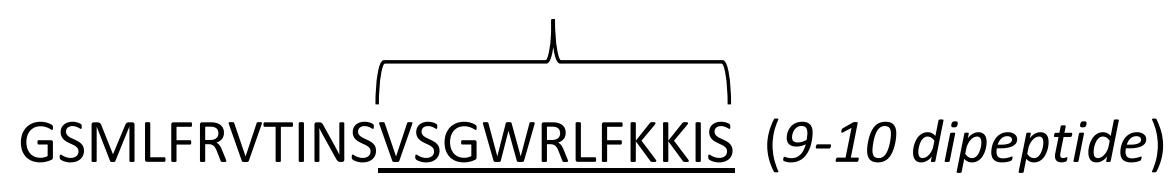

(b)

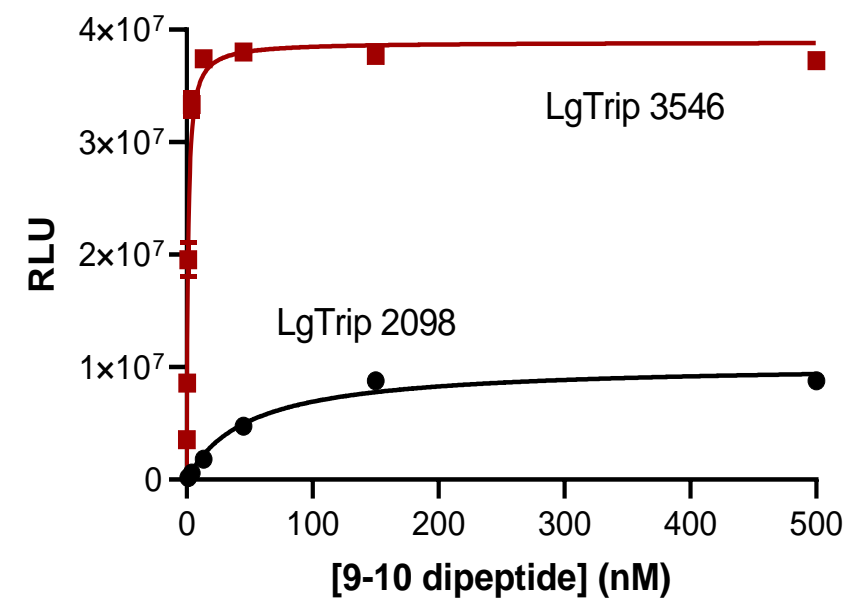

(c)

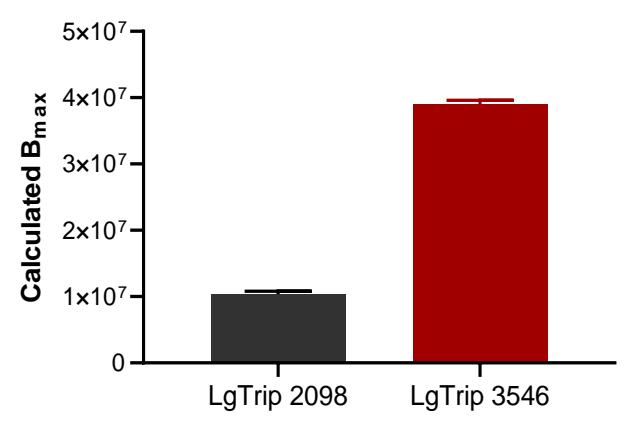

(d)

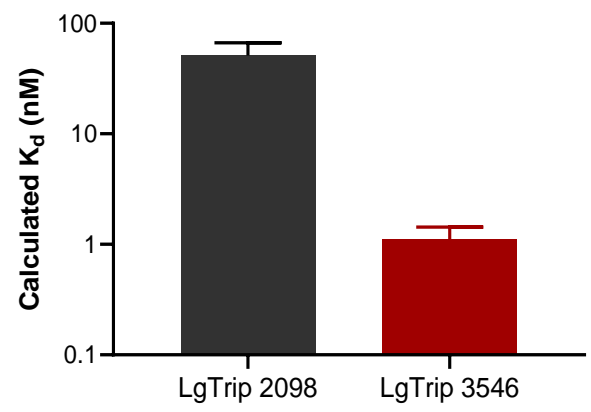

Figure S3. High affinity 9-10 dipeptide titrations. (a) Sequence of peptide representing parental $\beta$-strand $9+$ HiBiT (9-10 dipeptide). Note the HiBiT portion is underscored. (b) 9-10 dipeptide titration with either recombinant LgTrip 2098 or LgTrip 3546. (c) Calculated $B_{\text {max }}$ from the data in panel b. (d) Calculated $K_{d}$ from the data in panel $b$. 


\section{Figure S3 (continued)}

(e)

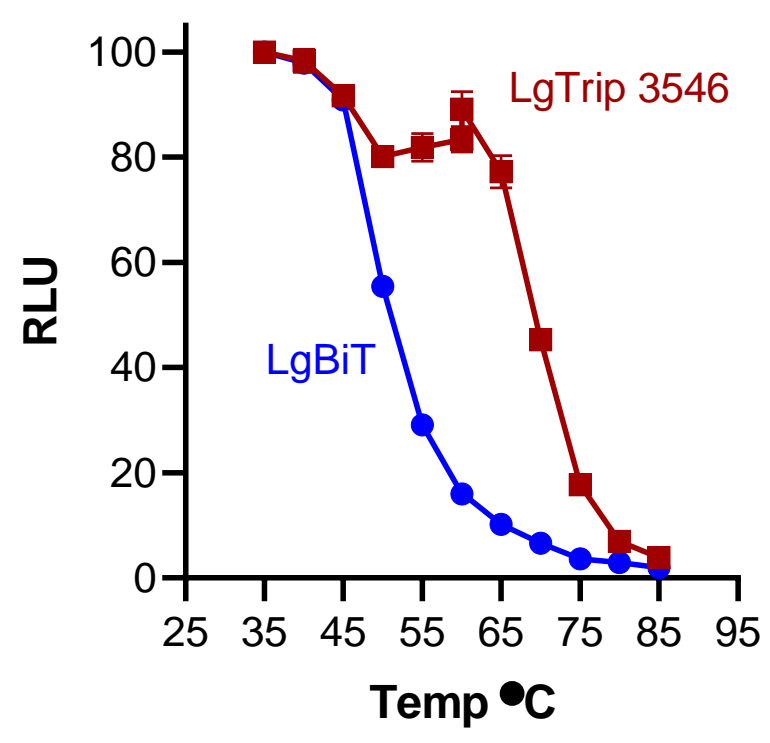

Figure S3 (cont'd). (e) Thermal stability of purified LgTrip 3546 and LgBiT, based on remaining activity at ambient temperature in the presence of saturating complementary peptide added after a $1 \mathrm{~h}$ challenge across a temperature gradient. $60^{\circ} \mathrm{C}$ data is presented as duplicate points because it was redundant in both thermal cyclers used to establish the gradient. Data = mean of 8 independent samples (3 experiments) plotted with SEM. LgTrip 2098 is not included in this data set, but as indicated in Figure S1 (similar conditions) it loses approximately half of its activity following a $1 \mathrm{~h}$ exposure to $37^{\circ} \mathrm{C}$. 
Figure S4

\begin{tabular}{|c|c|c|c|c|}
\hline & 8 & 18 & 28 & 3 \\
\hline LgBiT & MVFTLEDFVG & DWEQTAAYNL & DQVLEQGGVS & SLLQNLAVSV \\
\hline 098 & IVFTLEDFVG & DWEQTAAYNL & DQVLEQGGVS & SLLQNLAVSV \\
\hline \multirow[t]{2}{*}{3546} & VFTLDDFVG & $\begin{array}{c}\text { DWEQTAAYNL } \\
\beta 1\end{array}$ & DQVLEQGGVS & SLLQNLAVSV \\
\hline & 48 & 58 & 68 & \\
\hline gBiT & TPIQRIVRSG & ENALKIDIHV & IIPYEGLSAD & QMAQIEEVFK \\
\hline 2098 & PIQRIVRSG & ENALKIDIHV & IIPYEGLSAD & QMAQIEEVFK \\
\hline \multirow[t]{2}{*}{3546} & PIMRIVRSG & $\begin{array}{c}\text { ENALKIDIHV } \\
\beta 3\end{array}$ & IIPYEGLSAD & IEEVFK \\
\hline & 88 & 98 & 108 & 118 \\
\hline gBiT & VYPVDDHHF & KVILPYGTLV & IDGVTPNMLN & YEGIA \\
\hline 2098 & VVYPVDDHHF & KVILPYGTLV & IDGVTPNMLN & YFGRPYEGIA \\
\hline \multirow[t]{3}{*}{3546} & NYPVDDHHF & KVILPYGTLV & IDGVTPNKKLN & YFGRPYEGIA \\
\hline & & $\beta 4$ & $\beta 5$ & $\beta 6$ \\
\hline & 128 & 138 & 148 & 157 \\
\hline LgBiT & /FDGKKITVT & GTLWNGNKI I & DERLITPDGS & MLFRVTINS \\
\hline 2098 & VFDGKKITVT & GTLWNGNKII & DERLITPD-- & ------- \\
\hline \multirow[t]{2}{*}{3546} & VFDGKKITIT & GTLWNGNKII & DERLITPD - - & -------- \\
\hline & & & & (T) \\
\hline
\end{tabular}

Figure S4. LgTrip 3546 amino acid substitutions. Shown is the protein sequence alignment between LgBiT, LgTrip 2098, and LgTrip 3546. Amino acid substitutions in LgTrip 3546 are highlighted in dark red and underscored. Putative $\beta$-barrel strands in LgTrip 3546 (based on Nluc structure doi: $10.2210 / \mathrm{pdb} 5 \mathrm{IBO} / \mathrm{pdb}$ ) are highlighted in gray and boxed. Putative $\beta 9$ in LgBiT (missing from LgTrip 2098 and LgTrip 3546) is highlighted using white letters and a black background. 


\section{Figure S5}

(a)

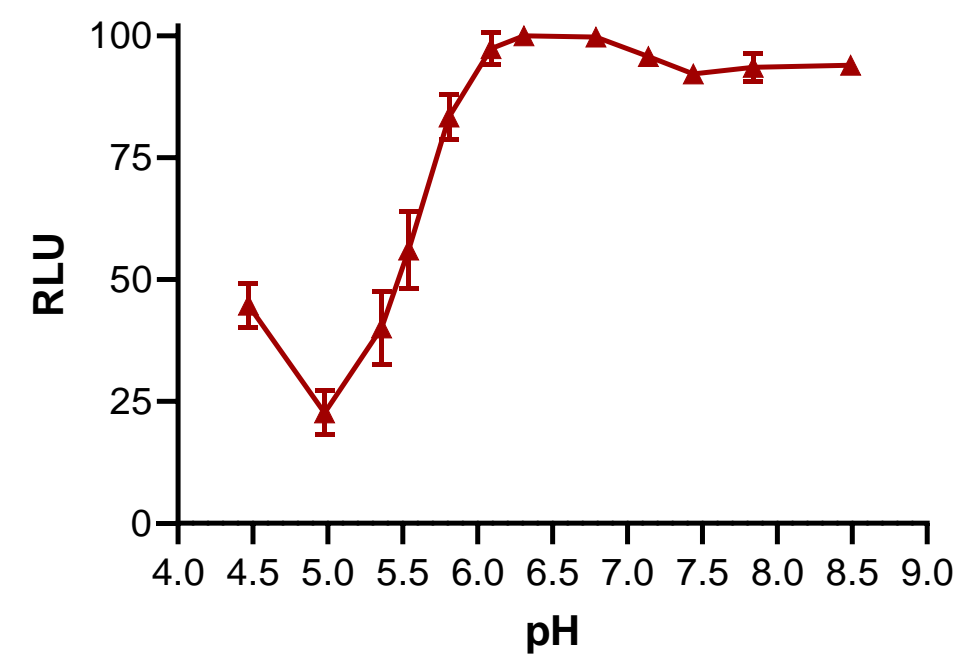

(b)

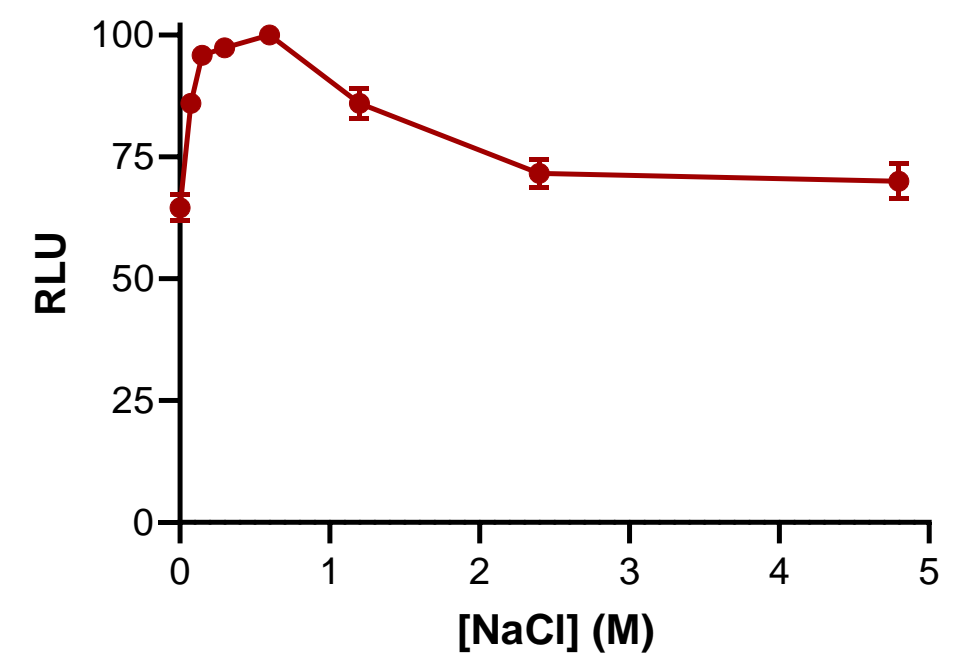

Figure S5. LgTrip 3546 is stable following exposure to a range of $\mathrm{pH}$ and $\mathrm{NaCl}$ concentrations. Purified LgTrip 3546 was incubated for $24 \mathrm{~h}$ in the presence of buffers with different $\mathrm{pH}$ (panel a) or different concentrations of $\mathrm{NaCl}$ (panel b). For both the $\mathrm{pH}$ and $\mathrm{NaCl}$ experiments samples to be assayed were diluted in a common buffer (see Experimental Section) and supplemented with a saturating concentration of 9-10 dipeptide. After 20 min Fz was added and samples were read for luminescence. Luminescence is presented as RLU normalized to the high points for $\mathrm{pH}$ (6.3) and $[\mathrm{NaCl}](0.6 \mathrm{M})$. Data represents the average of three independent experiments. Error bars represent SEM. 


\section{Figure S6}

(a)

\section{$\beta$-strand 9}

Peptide

Sequence

$\mathrm{H}_{2} \mathrm{O}$ solubility

245

GSMLFR RTINS

$x$

286

SSWKRGSMLFRVTINS

435

GSMLFRVTINSWK

$x$

492

GSMLFRVTINKWK

$x$

494

GSMLFRVTINRWK

$x$

496

GSMLFRVTINDWK

$x$

525

GRMLFRVTINSWK

$\mathrm{x}$

521

GKMLFRVTINSWK

(b)

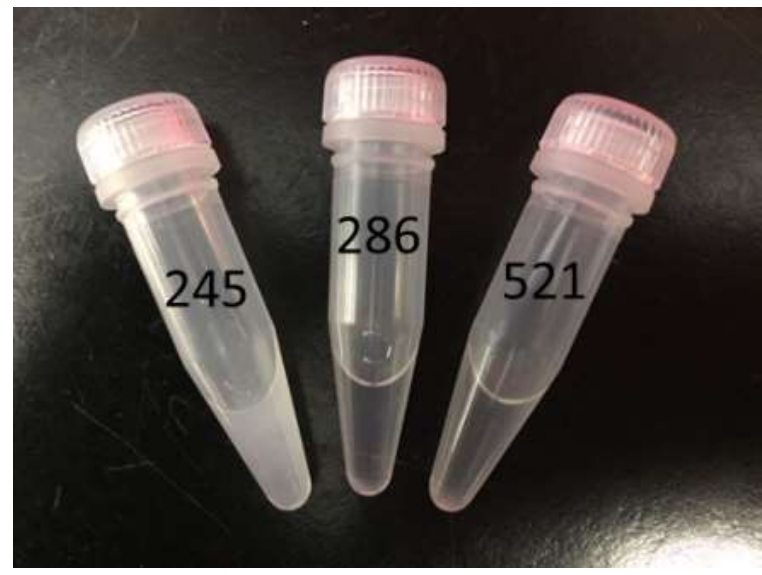

Figure S6. Biochemical characterization of $\beta$ strand 9 peptides. (a) Names, sequences, and water-solubility of strand 9 peptides. Hydrophobic core residues are underlined. Residues in red were added to improve water solubility. Trp (W), shown in green, enables quantification using absorbance at $280 \mathrm{~nm}$. (b) Aqueous solutions for peptides 245,286 , and 521. Peptides were deemed water soluble if 5 $\mathrm{mM}$ solutions remained transparent after a single freeze-thaw. 
Figure S6 (continued)

(c)

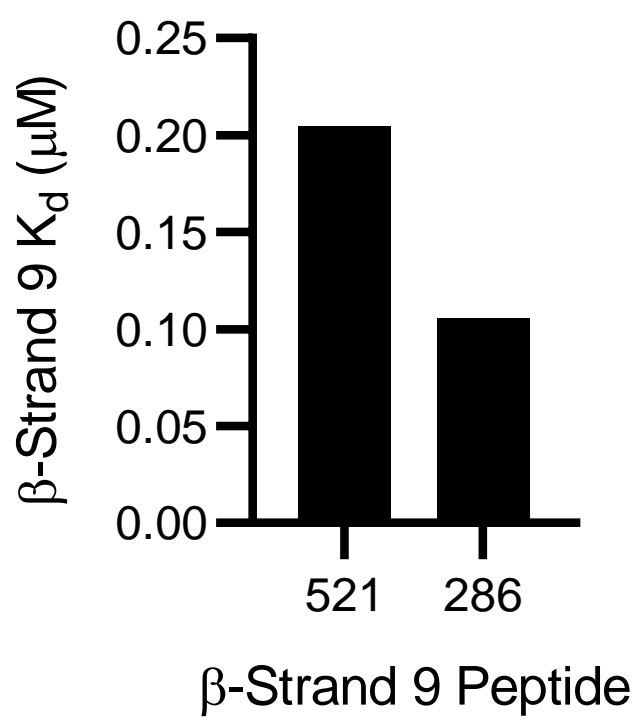

(d)

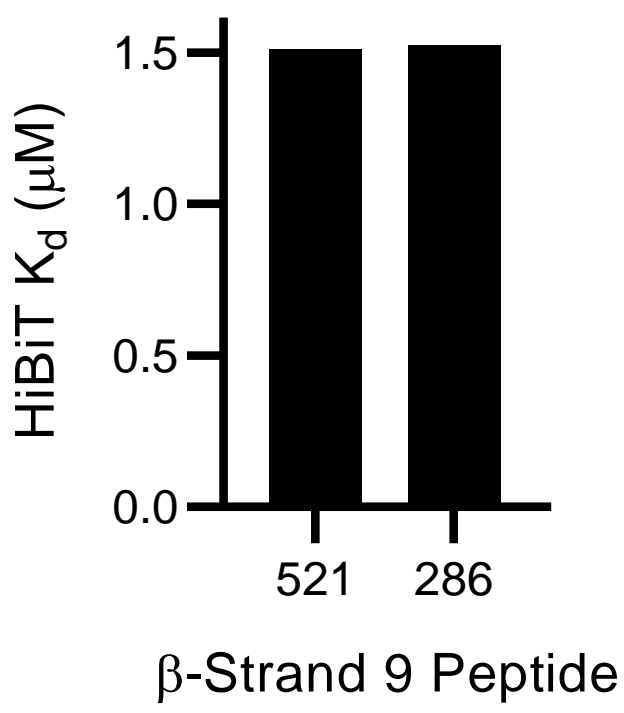

Figure S6 (cont'd). Biochemical characterization of synthetic $\beta$-strand 9 peptides. (c) Strand 9 affinities with saturating $\mathrm{HiBiT}$. (d) HiBiT affinities with saturating peptide 521 or 286. 
Figure S6 (continued)

(e)
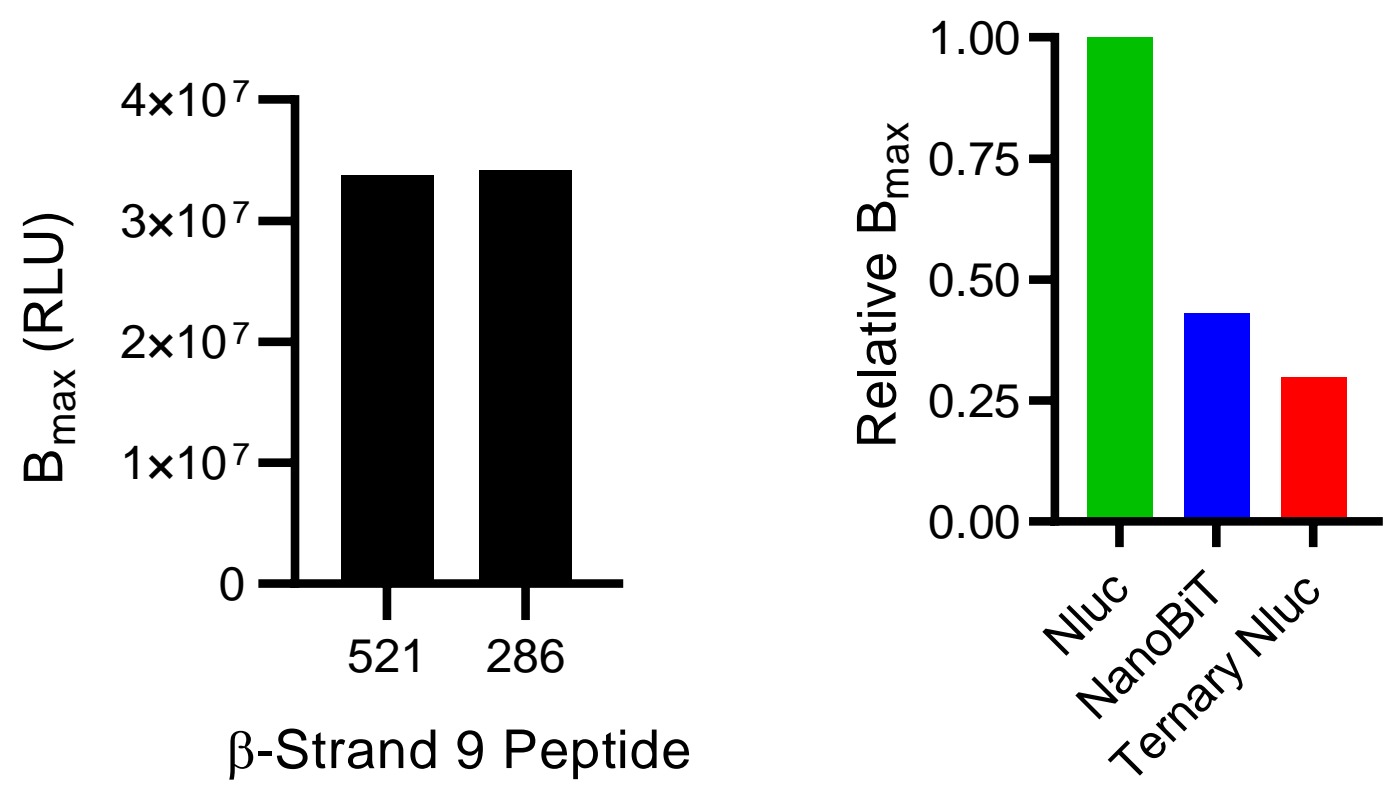

Figure S6 (cont'd). Biochemical characterization of synthetic $\beta$-strand 9 peptides and ternary Nluc compared to NanoBiT ( $\mathrm{LgBiT}+\mathrm{VS}-\mathrm{HiBiT}$ ) and Nluc. (e) Maximum signal when both strand 9 peptide and VS-HiBiT are saturating. (f) Comparison of maximum signals (normalized to Nluc) using equimolar quantities of LgTrip, LgBiT, and Nluc. 


\section{Figure S7}

(a)

$\beta$-Strand 9 (peptide 521)

HaloTag ${ }^{\circledR}$ Fusion

MKHHHHHHAEIGTGFPFDPHYVEVLGERMHYVDVGPRDGTPVLFL

HGNPTSSYVWRNIIPHVAPTHRCIAPDLIGMGKSDKPDLGYFFDDHV

RFMDAFIEALGLEEVVLVIHDWGSALGFHWAKRNPERVKGIAFMEFI

RPIPTWDEWPEFARETFQAFRTTDVGRKLIIDQNVFIEGTLPMGVVR

PLTEVEMDHYREPFLNPVDREPLWRFPNELPIAGEPANIVALVEEYM

DWLHQSPVPKLLFWGTPGVLIPPAEAARLAKSLPNCKAVDIGPGLNL

LQEDNPDLIGSEIARWLSTLEISGGGSGGSSGGGSGGSSGGGSGGSS

GGKMLFRVTINSWK

HaloTag $^{\circledR}$

6-His tag

Linker

(b)

$\beta$-Strand 10 (VS-HiBiT)

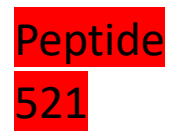

HaloTag ${ }^{\circledR}$ Fusion

MKHHHHHHAEIGTGFPFDPHYVEVLGERMHYVDVGPRDGTPVLFL

VS-HiBiT

HGNPTSSYVWRNIIPHVAPTHRCIAPDLIGMGKSDKPDLGYFFDDHV

RFMDAFIEALGLEEVVLVIHDWGSALGFHWAKRNPERVKGIAFMEFI

RPIPTWDEWPEFARETFQAFRTTDVGRKLIIDQNVFIEGTLPMGVVR

PLTEVEMDHYREPFLNPVDREPLWRFPNELPIAGEPANIVALVEEYM

DWLHQSPVPKLLFWGTPGVLIPPAEAARLAKSLPNCKAVDIGPGLNL

LQEDNPDLIGSEIARWLSTLEISGGGSGGSSGVSVSGWRLFKKIS

Figure S7. Antibody labeling with HaloTag-Ternary Nluc fusion proteins. (a) Protein sequence of polyHis-HaloTag-peptide 521. (b) Protein sequence of polyHis-HaloTag-VS-HiBiT. 


\section{Figure S7 (continued)}

(c)

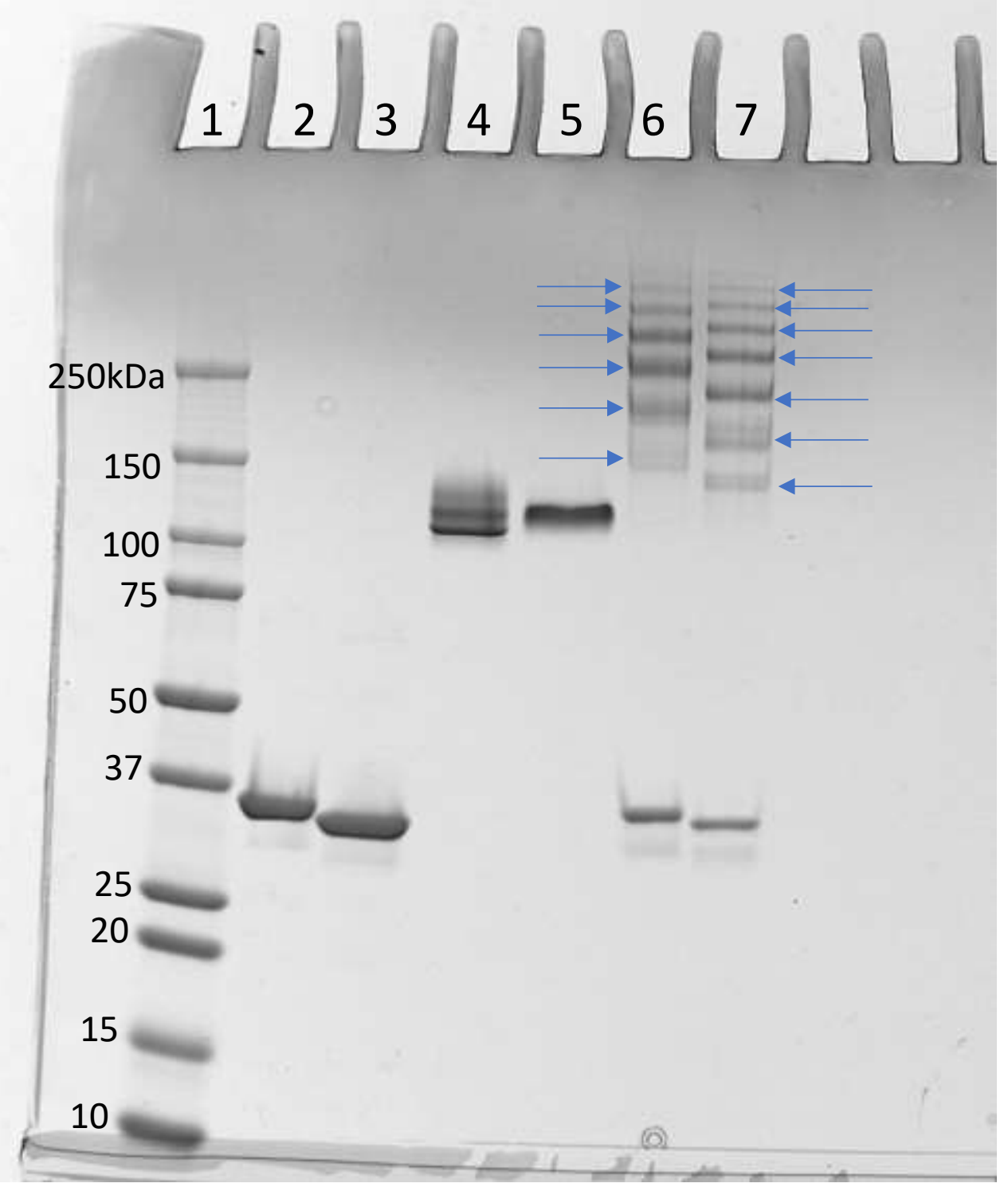

Figure S7 (cont'd). (c) Representative native PAGE image of antibody labeling with HaloTagTernary Nluc fusion proteins. HaloTag fusions to peptide 521 or VS-HiBiT were purified and used to label mouse anti-human IL-6 antibodies. Lanes: 1) MW standards, 2) HaloTag-peptide $521,3)$ HaloTag-VS-HiBiT, 4) unlabeled anti-IL-6 antibody clone 5IL6, 5) unlabeled anti-IL-6 antibody clone 505E 9A12 A3,6) clone 5IL6 antibody labeled with HaloTag-peptide 521, and 7) clone 505E 9A12 A3 antibody labeled with HaloTag-VS-HiBiT. Shown is a representative gel from a single lot of labeled antibody. Similar results were obtained for multiple lots. 


\section{Figure S8}

(a)

\begin{tabular}{l|cccc} 
& $\begin{array}{l}\text { Antibody 2- } \\
\text { HT-8GS- } \\
\text { peptide 521 }\end{array}$ & $\begin{array}{l}\text { Antibody 2- } \\
\text { HT-24GS- } \\
\text { peptide 521 }\end{array}$ & $\begin{array}{l}\text { Antibody 2- } \\
\text { HT-8GS-VS- } \\
\text { HiBiT }\end{array}$ & $\begin{array}{l}\text { Antibody 2- } \\
\text { HT-24GSVS- } \\
\text { HiBiT }\end{array}$ \\
\hline $\begin{array}{l}\text { Antibody 1-HT- } \\
8 \text { GS-peptide 521 }\end{array}$ & $\mathrm{x}$ & $\mathrm{x}$ & 1 & 2 \\
$\begin{array}{l}\text { Antibody 1-HT- } \\
24 G S-\text { peptide 521 }\end{array}$ & $\mathrm{x}$ & $\mathrm{x}$ & 3 & 4 \\
$\begin{array}{l}\text { Antibody 1-HT- } \\
8 \mathrm{GS}-\text {-VSHiBiT }\end{array}$ & 5 & 6 & $\mathrm{x}$ & $\mathrm{x}$ \\
$\begin{array}{l}\text { Antibody 1-HT- } \\
\text { 24GS-VSHiBiT }\end{array}$ & 7 & 8 & $\mathrm{x}$ & $\mathrm{x}$
\end{tabular}

(b)

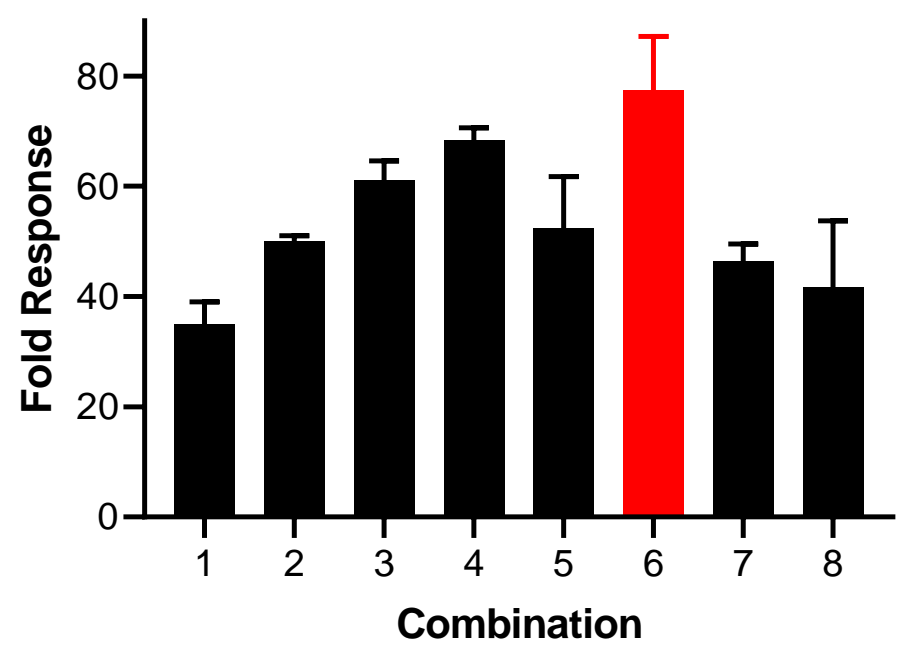

Figure S8. Screen to identify optimal anti-IL-6-based antibody reagents. Antibody 1 represents clone 505E 9A12 A3 and Antibody 2 represents clone 5IL6. Each antibody was labeled with peptide 521 or VS-HiBiT via HaloTag (with a linker (either 8 or 24GS) between HT and the peptide sequence. Eight combinations were screened against recombinant human IL-6 (rhIL-6). $100 \mu \mathrm{g} / \mathrm{mL}$ of each antibody $+1 \mu \mathrm{M}$ LgTrip 3546 was incubated $+/-10 \mathrm{ng} / \mathrm{mL}$ rhIL-6 for 90 min in PBSB. Luminescence was measured upon the addition of Fz. (a) Combinations tested. (b) Response (+rhIL-6/background signal ((-) rhIL-6)). $n=3$, variability expressed as SD. 


\section{Figure S9}

(a)

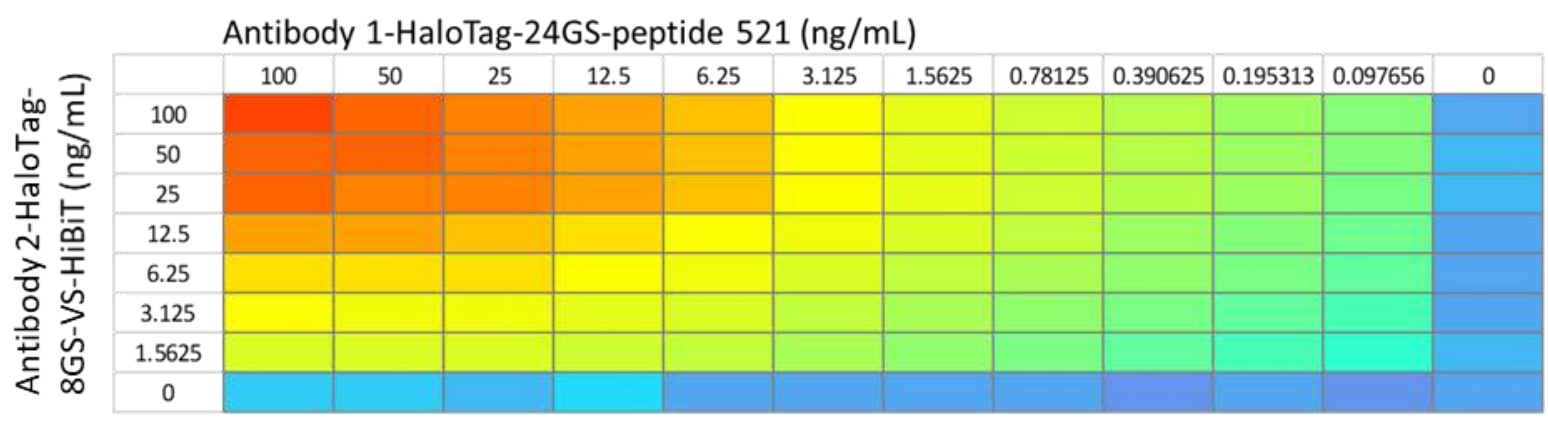

Antibody concentrations were varied in a matrix across and down the plate using a single [LgTrip 3546] (or the reverse) and analyzed using $+/-5 \mathrm{ng} / \mathrm{mL}$ rhlL-6

(b)

Optimizing [LgTrip 3546]

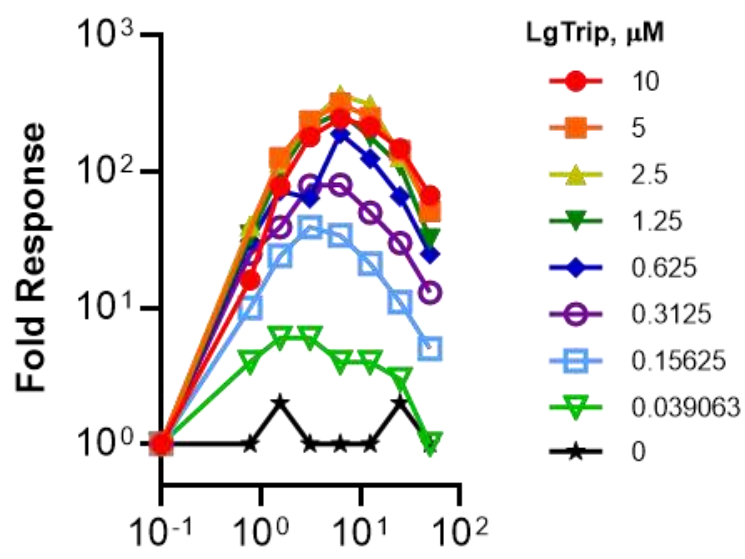

[Labeled anti-IL-6 antibody]

$(\mathrm{ng} / \mathrm{mL})$ (c)

\section{Optimizing [Labeled Anti-IL-6 Antibody]}

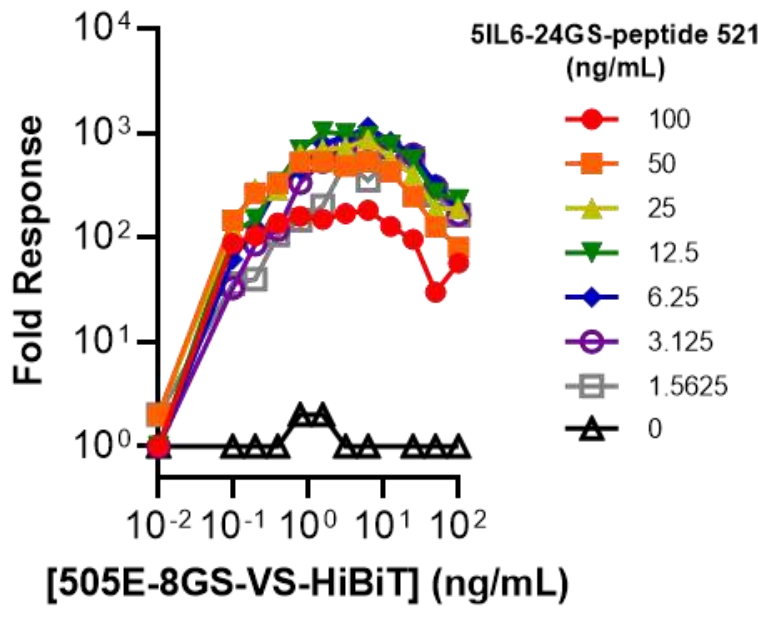

Figure S9. Identifying optimal reagent concentrations. (a) Schematic of matrix experiment in which assay reagents were titered against each other across and down duplicate plates, one in the absence of rhlL-6 and one in the presence of rhIL-6. (b) Matrix experiment optimizing for LgTrip 3546 concentration. (c) Matrix experiment for optimizing concentrations of peptide 521and VS-HiBiT-labeled antibodies. Fold response $(5 \mathrm{ng} / \mathrm{mL}$ rhlL-6, $90 \mathrm{~min}$ incubation) values in panels $a$ and $b$ represent the ratios of RLU values obtained from the (+)hrlL-6 plate to that of the (-)hrlL-6 plate. 
Figure S9 (continued)

(d)

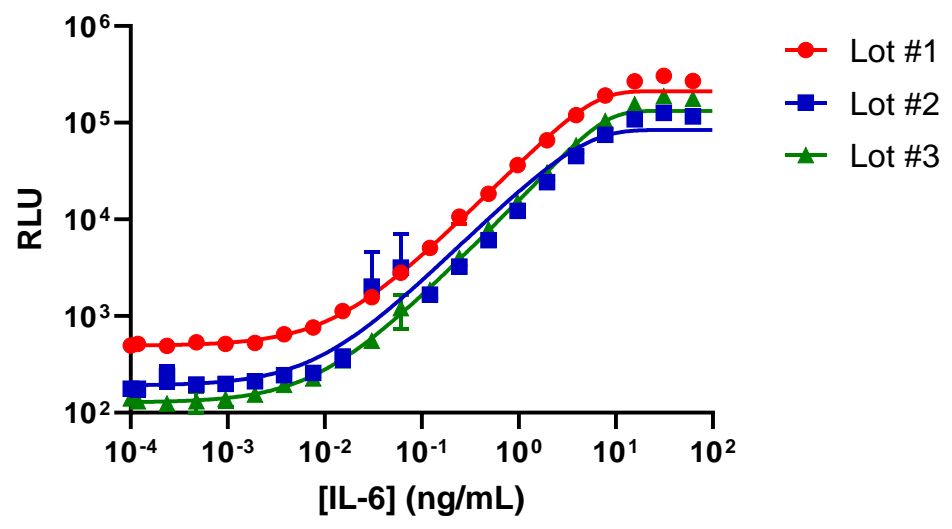

(e)

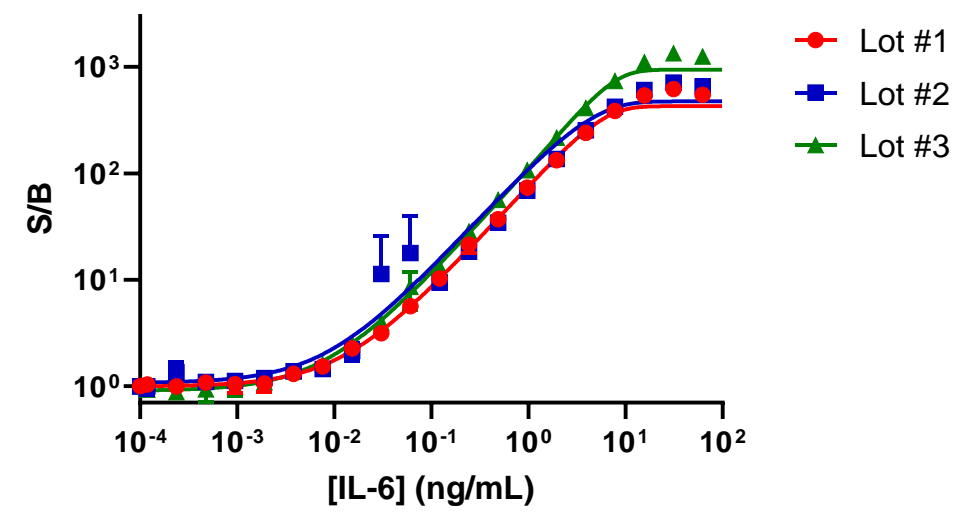

Figure S9 (contd). rhlL-6 dose response curves (90 min incubation) for three lots of antibodies labeled with HaloTag-Ternary Nluc fusion proteins demonstrating lot-to-lot reproducibility. Panel (d) displays luminescence signal (RLU). Panel (e) shows signal over background (S/B). $n=3$, variability expressed as SD.

S-24 


\section{Figure S10}

(a)

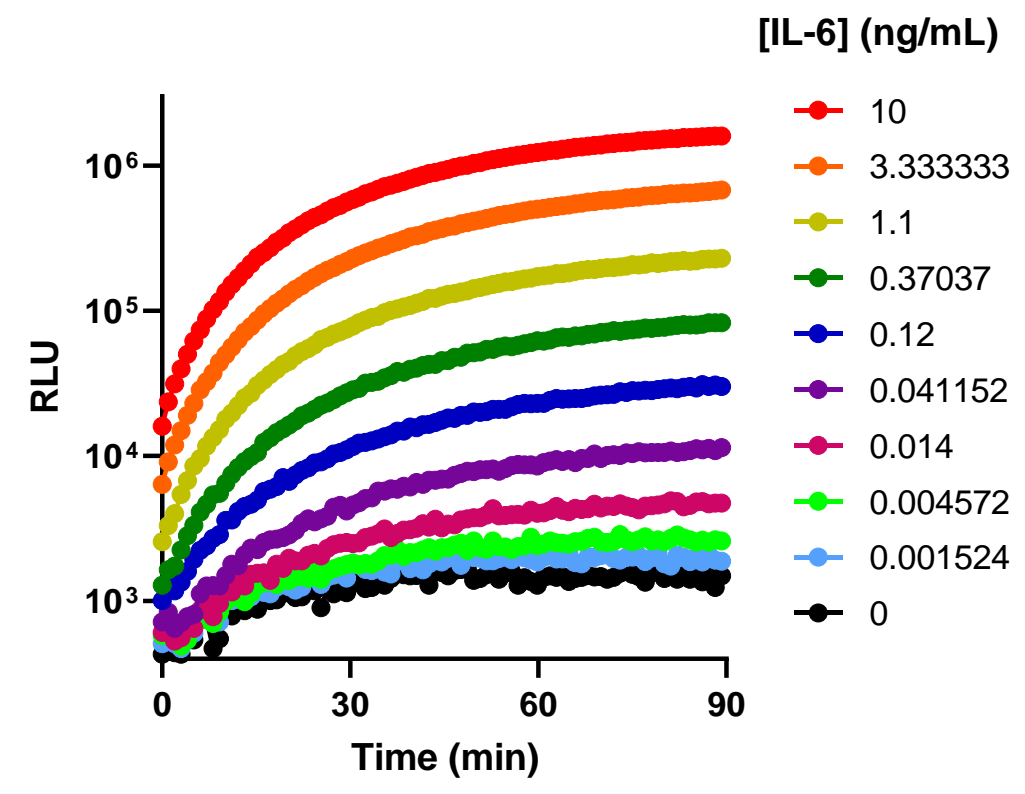

(b)

(c)

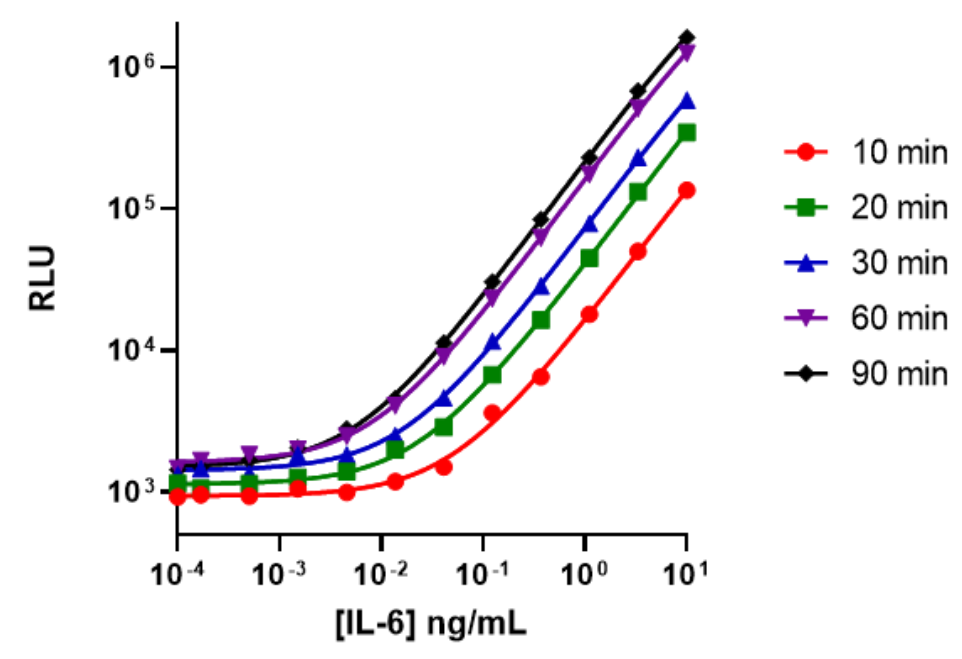

\begin{tabular}{|c|c|}
\hline Time (min) & $\begin{array}{c}\text { Approx. LOD } \\
(\mathrm{ng} / \mathrm{mL})\end{array}$ \\
\hline 10 & 0.104 \\
\hline 20 & 0.050 \\
\hline 30 & 0.031 \\
\hline 60 & 0.015 \\
\hline 90 & 0.011 \\
\hline
\end{tabular}

Figure S10. (a) Time course for solution-based Ternary Nluc IL-6 immunoassay using variable concentrations of rhIL-6. (b) Conversion of the kinetic data shown in panel a to display dose response curves from which estimated LOD calculations were performed (panel c). 


\section{Figure S10 (continued)}

(d)

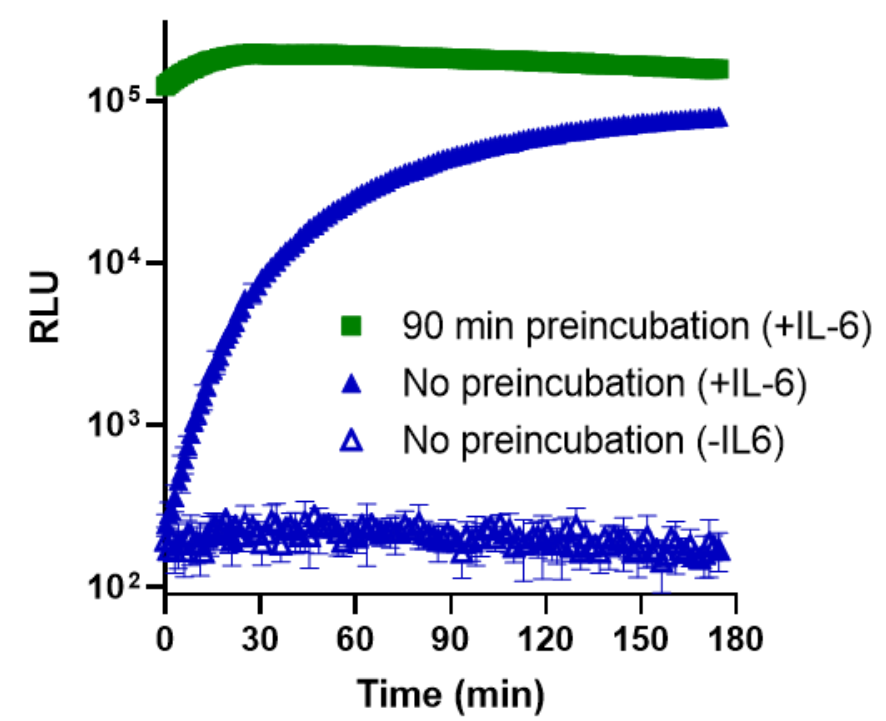

(e)

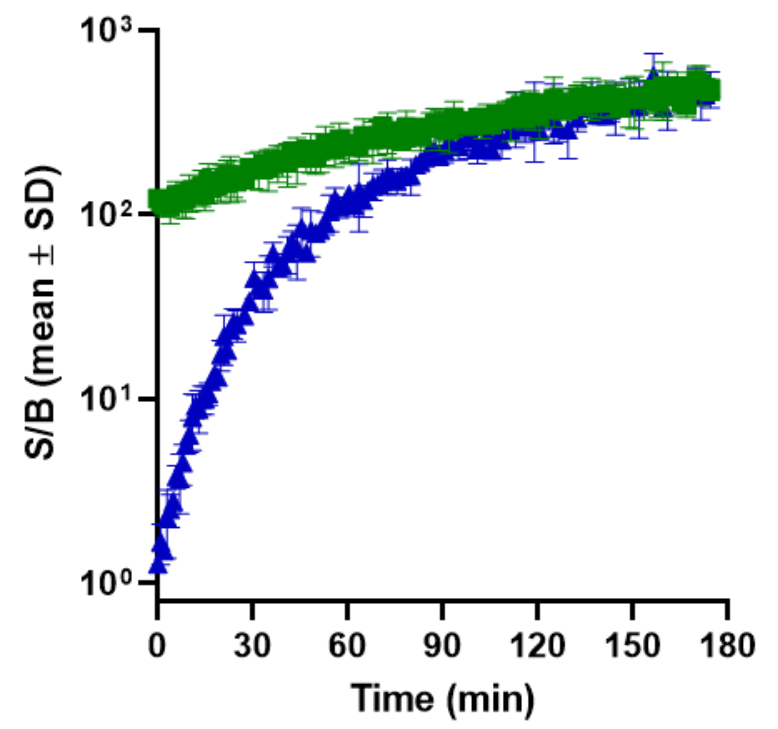

Figure $\mathbf{S 1 0}$ (cont'd). (d) Time course for solution-based Ternary Nluc IL-6 immunoassay using 5 $\mathrm{ng} / \mathrm{mL}$ rhlL-6. (e) Calculation of signal over background (S/B) for the kinetic data in panel $\mathrm{d}$. Shown are means $\pm S D(n=3)$. 


\section{Figure S11}

(a)

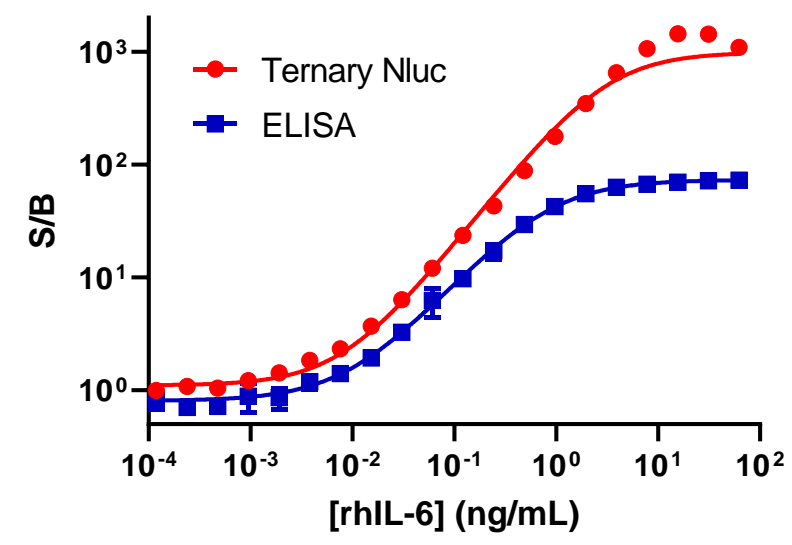

(b)

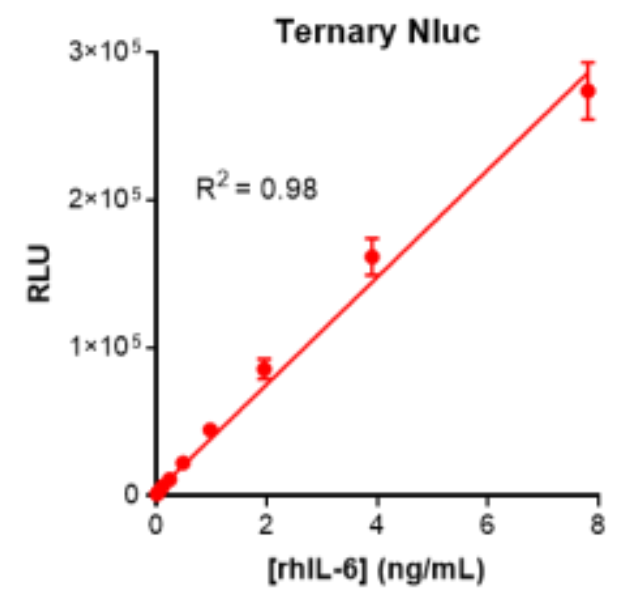

(c)

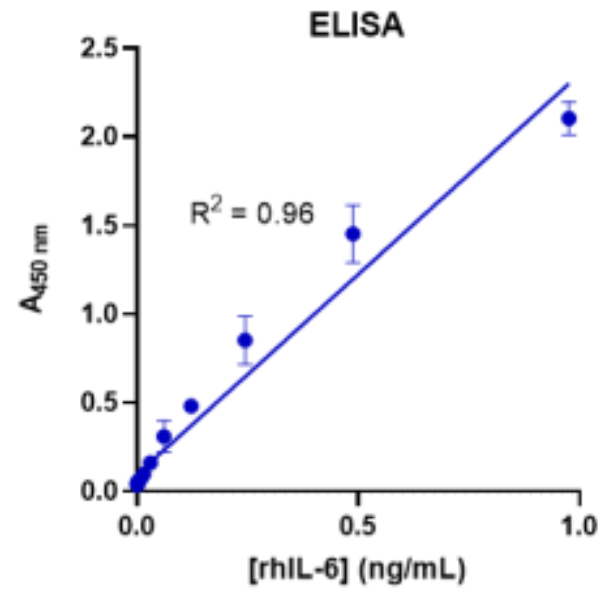

(d)

\begin{tabular}{|c|c|c|}
\hline & $\begin{array}{c}\text { Ternary } \\
\text { Nluc }\end{array}$ & ELISA \\
\hline LOD & $2.1 \mathrm{pg} / \mathrm{mL}$ & $11 \mathrm{pg} / \mathrm{mL}$ \\
\hline LOQ & $4.3 \mathrm{pg} / \mathrm{mL}$ & $31 \mathrm{pg} / \mathrm{mL}$ \\
\hline ULOQ & $16.2 \mathrm{ng} / \mathrm{mL}$ & $3.2 \mathrm{ng} / \mathrm{mL}$ \\
\hline
\end{tabular}

Figure S11. Assay performance for solution-based Ternary Nluc assay compared to ELISA. (a) hrIL-6 Dose response for Ternary Nluc and standard ELISA displayed as S/B to normalize the difference in raw signals (mean \pm SEM, $n=3$ ). Linear plots of ternary Nluc (panel $\mathbf{b}$ ) and Invitrogen human IL-6 Instant ELISA (panel c) and calculations of assay performance. (d) LOD, LLOQ, and ULOQ were calculated as described in the Experimental Section. 


\section{Figure S11 (continued)}

(e)

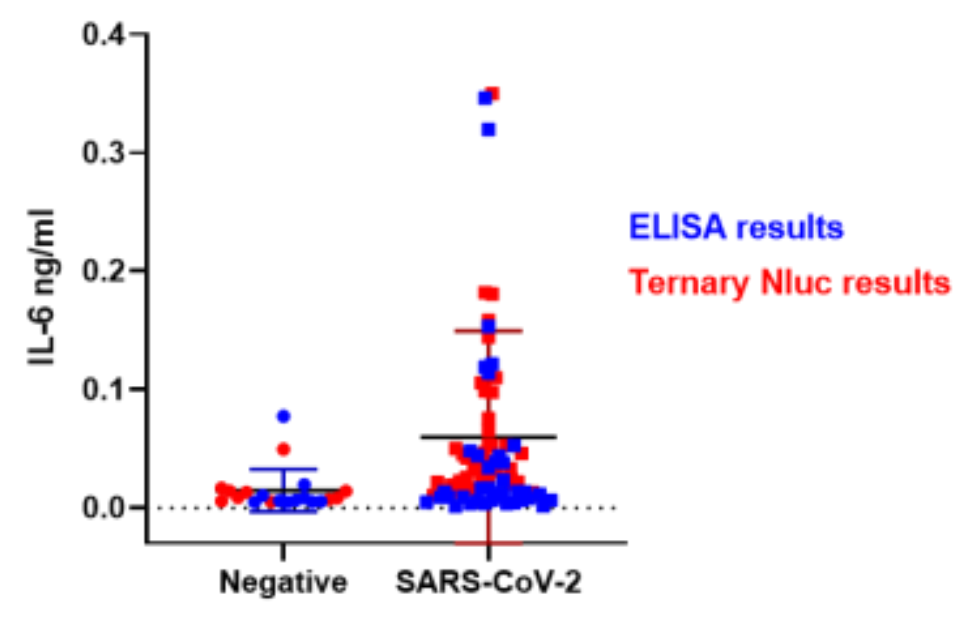

(f)

\section{Bland-Altman Analysis of [lL-6 $\mathrm{ng} / \mathrm{ml}]$ human samples}

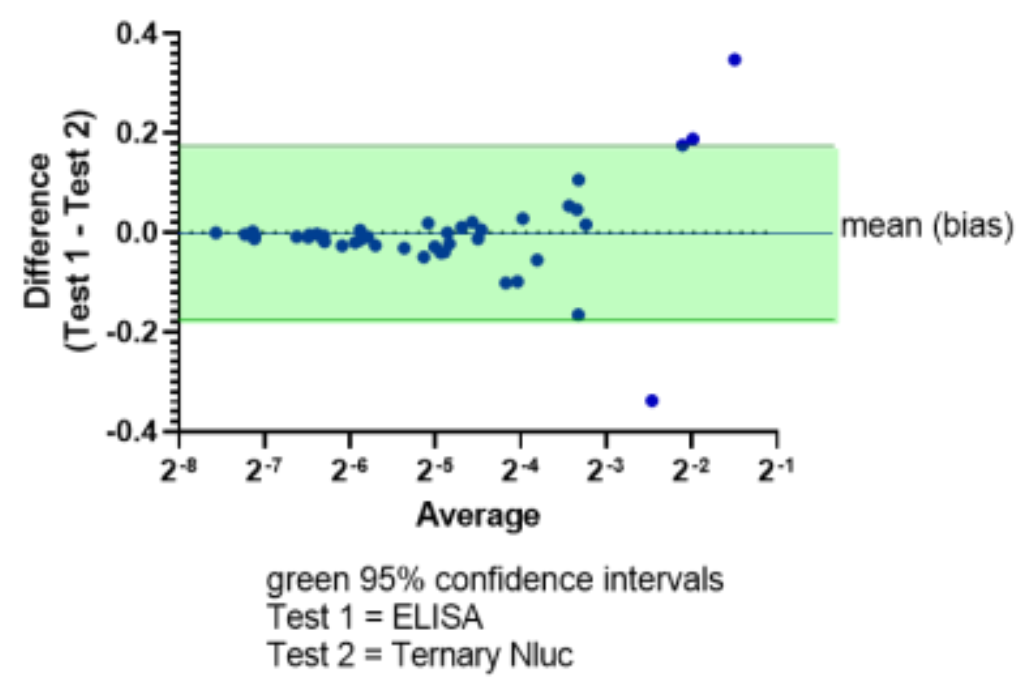

Figure S11 (cont'd). (e) IL-6 analysis of human samples overlaid with the ELISA results analyzing the same negative, presumed "normal" plasma samples $(n=10)$ and SARS-CoV-2 serum from individuals who experienced a severe clinical course requiring hospitalization $n=39$. (f) BlandAltman analysis of data presented in panel e showing good agreement between the ELISA and Ternary Nluc IL- 6 assay with mean bias \pm SD as $-0.004 \pm 0.09 \mathrm{ng} / \mathrm{mL}$ and limits of agreement of 0.18 and $0.17 \mathrm{ng} / \mathrm{mL}$. 


\section{Figure S12}

(a)

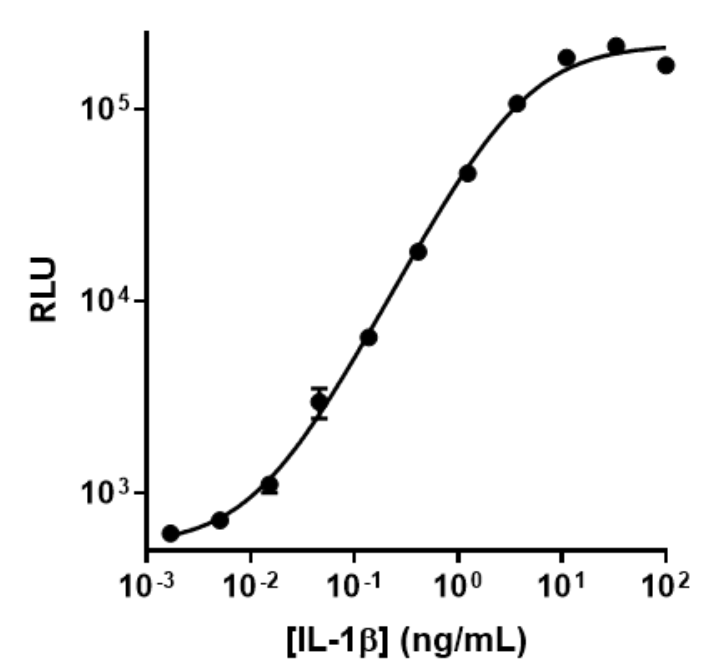

(c)

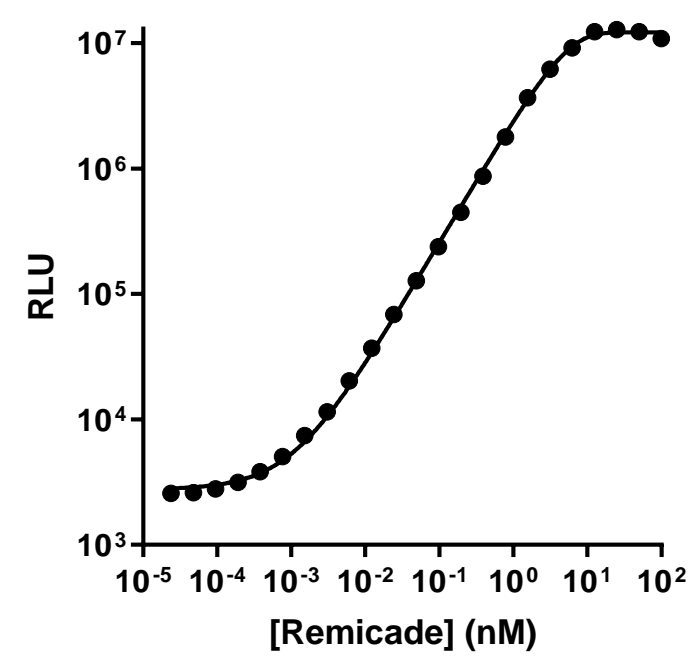

(b)

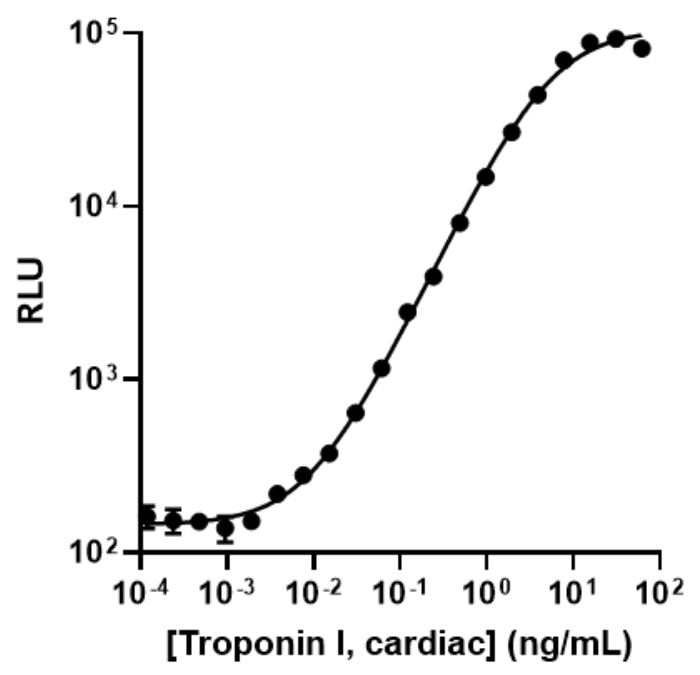

Figure S12. Dose response curves for ternary Nluc based assays for additional model systems. HaloTag labeling based systems are shown for IL-1 $\beta$ (panel a) and cardiac troponin I (panel b). A ternary Nluc genetic fusion approach is shown for the anti-TNF $\alpha$ therapeutic, Remicade. $n=3$, variability expressed as SD. 


\section{Figure S13}

(a)

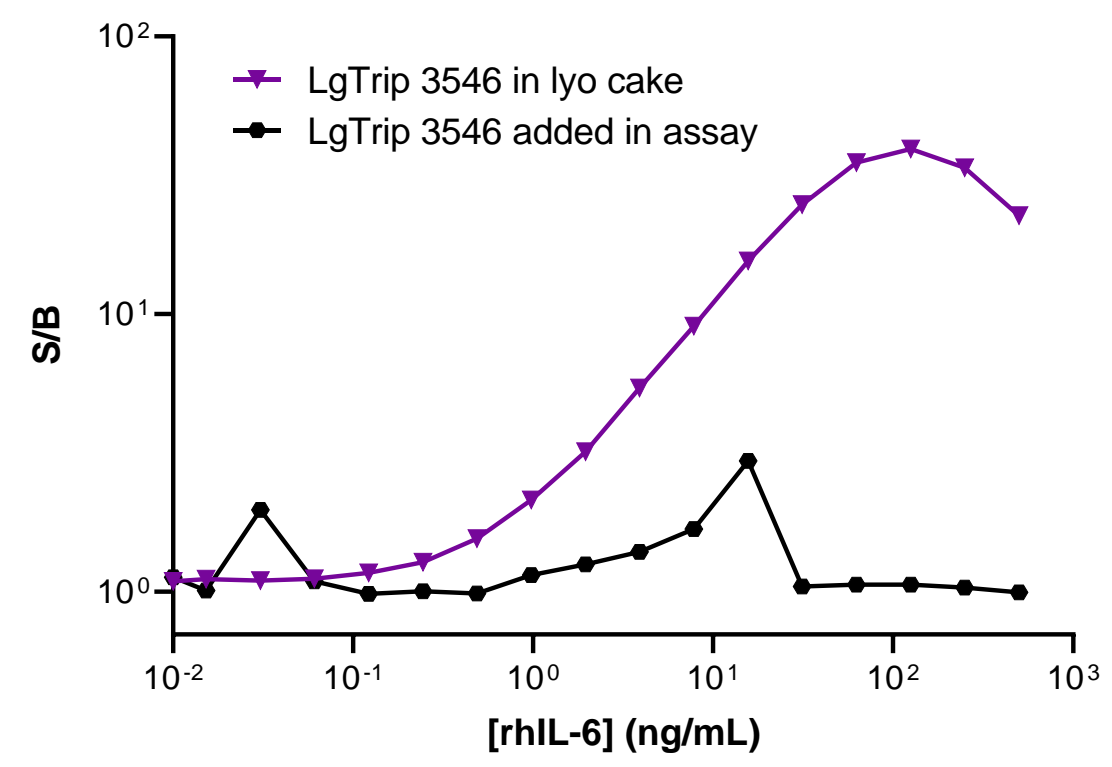

(b)

(c)
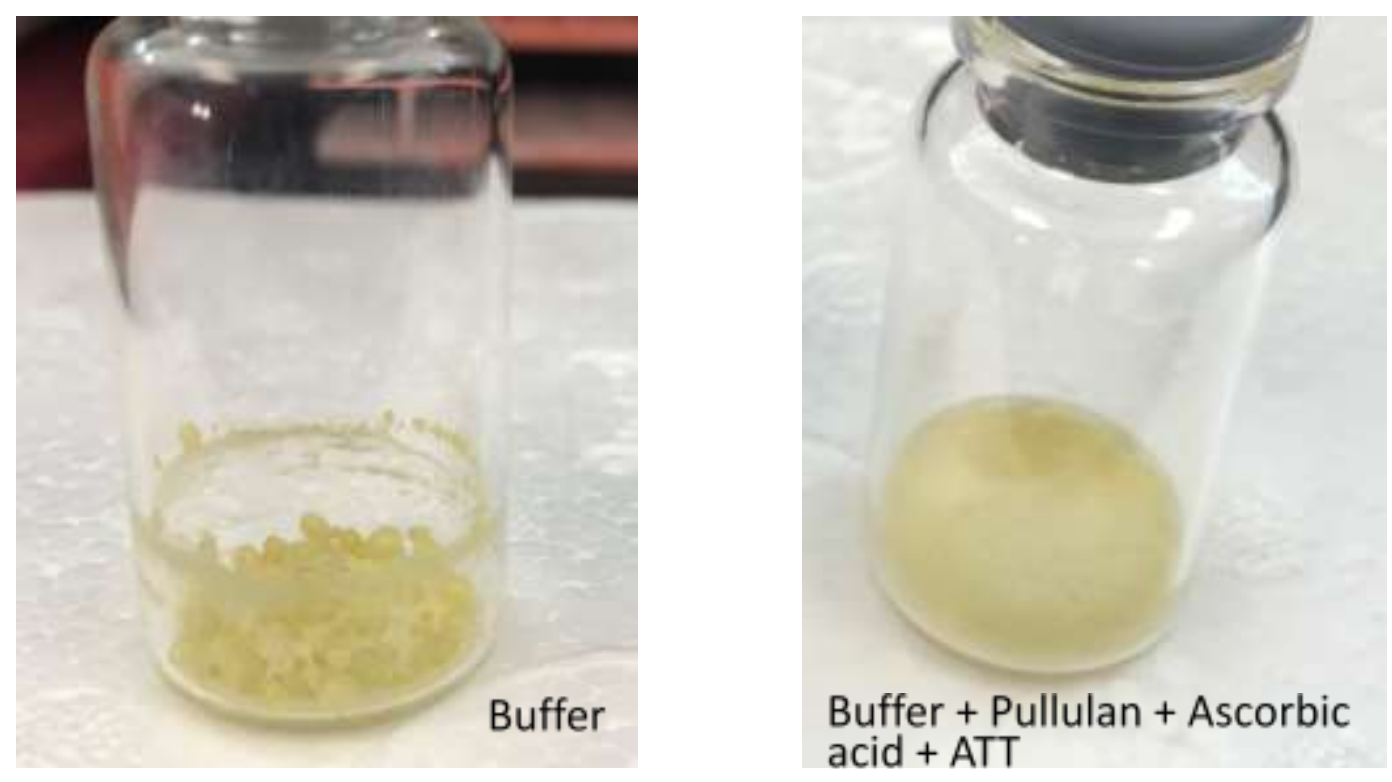

Figure S13. Initial formulation studies for lyophilization of IL-6 detection components. (a) Formulation of antibody conjugates with $5 \mathrm{mM} \mathrm{ATT}, 5 \mathrm{mM}$ ascorbic acid, and $2.75 \% \mathrm{w} / \mathrm{v}$ pullulan +/- LgTrip 3546 in lyophilized cakes. Cakes lyophilized without LgTrip 3546 displayed no IL-6 response. (b, c) Lyophilization of IL-6 detection components in buffer or buffer plus Pullulan, Acorbic acid, and ATT. 


\section{Figure S14}

(a)

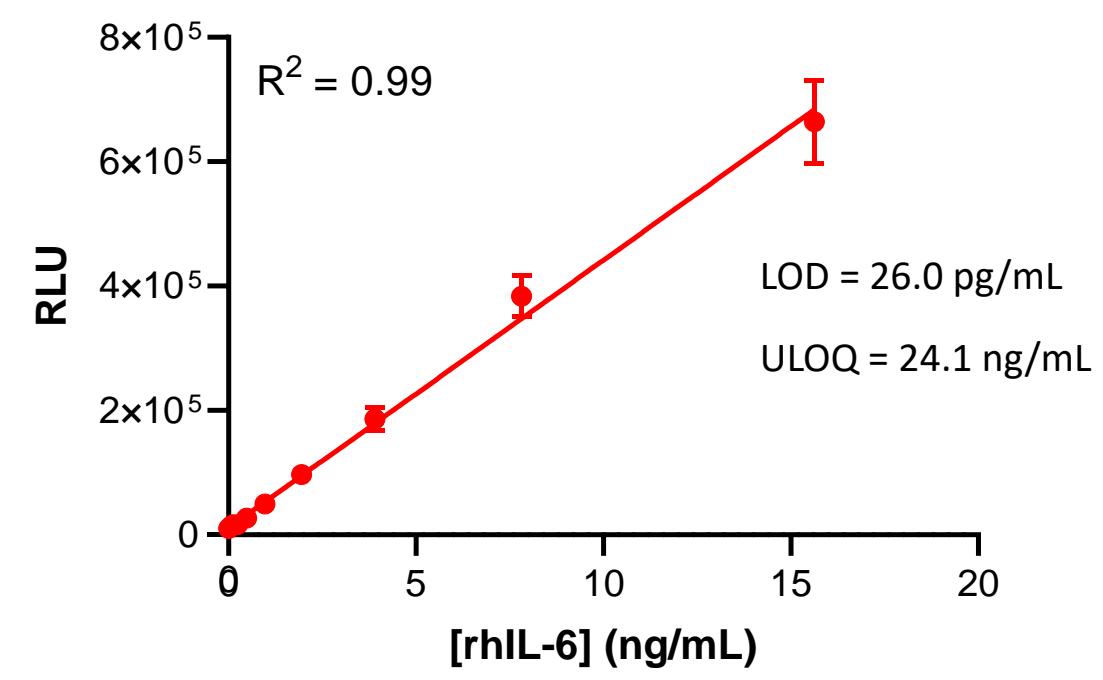

(b)

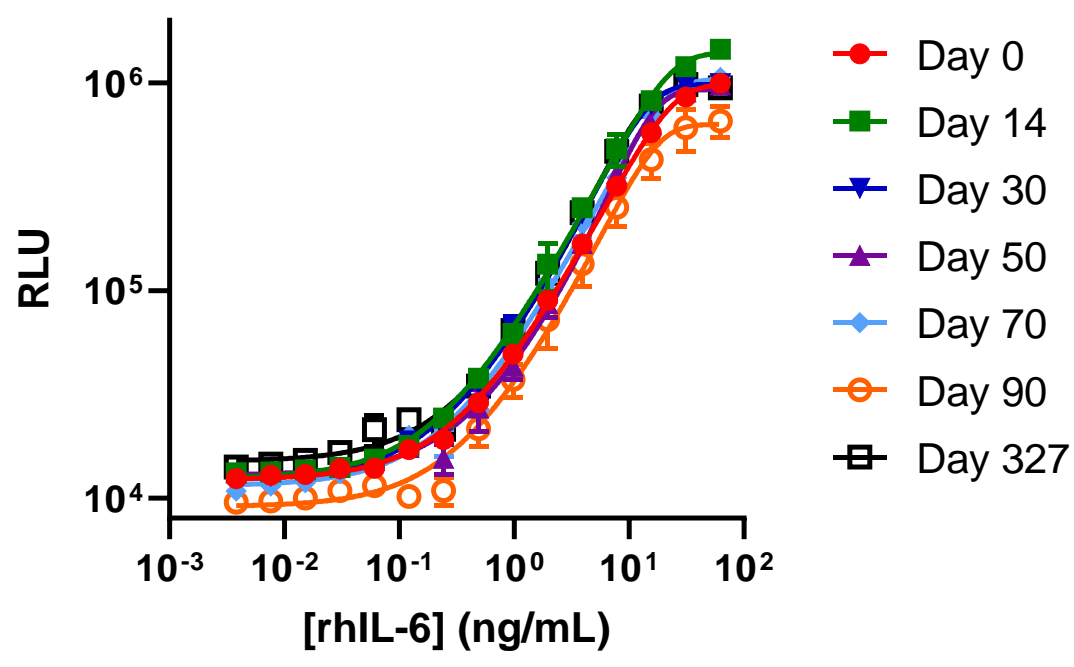

Figure S14. (a) Linear plot of the rhIL-6 dose response curve for the lyophilized ternary Nluc based IL- 6 immunoassay (90 min incubation time). Lyophilized cakes were reconstituted in PBSB and $50 \mu \mathrm{L}$ was added to 96-well microtiter plates containing rhIL-6. (b) Raw RLU values associated with Figure 5. Plates incubated at ambient temperature for 90 min. Final assay reagent concentrations were $60 \mathrm{ng} / \mathrm{mL}$ HiBiT-labeled antibody, $30 \mathrm{ng} / \mathrm{mL}$ peptide 521-labeled antibody, $1 \mu \mathrm{M}$ LgTrip 3546, and $5 \mu \mathrm{M}$ Fz. Shown are mean RLU values, $n=3$, of a representative experiment, with variability expressed as SD. LOD and ULOQ were calculated as described in the Experimental Section. 


\section{Figure S14 (continued)}

(c)

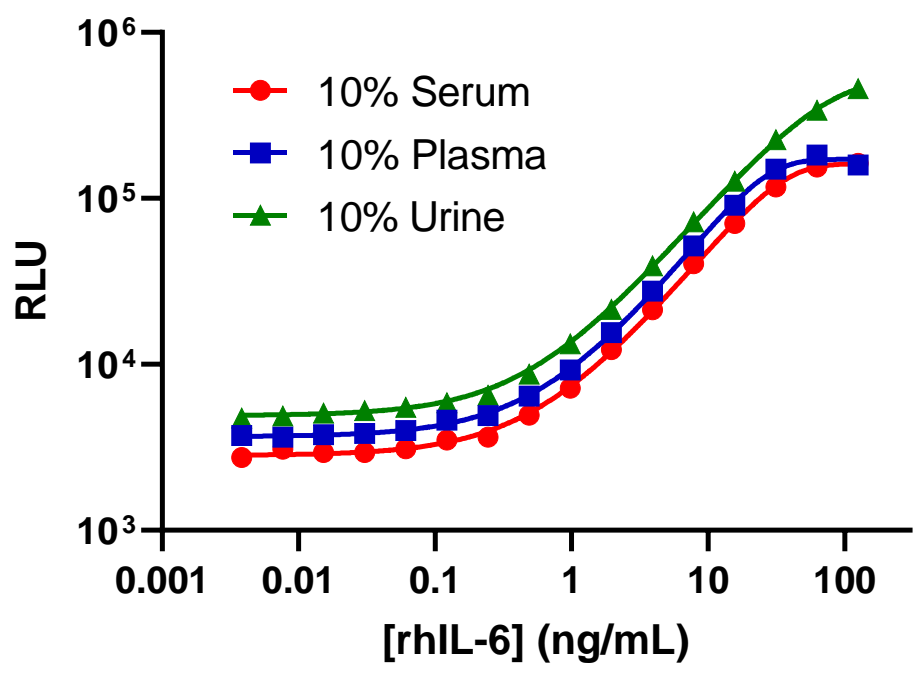

Figure S14 (cont'd). (c) Raw RLU values associated with Figure 6. $n=3$, variability expressed as SD. 


\section{Figure S15}

(a)

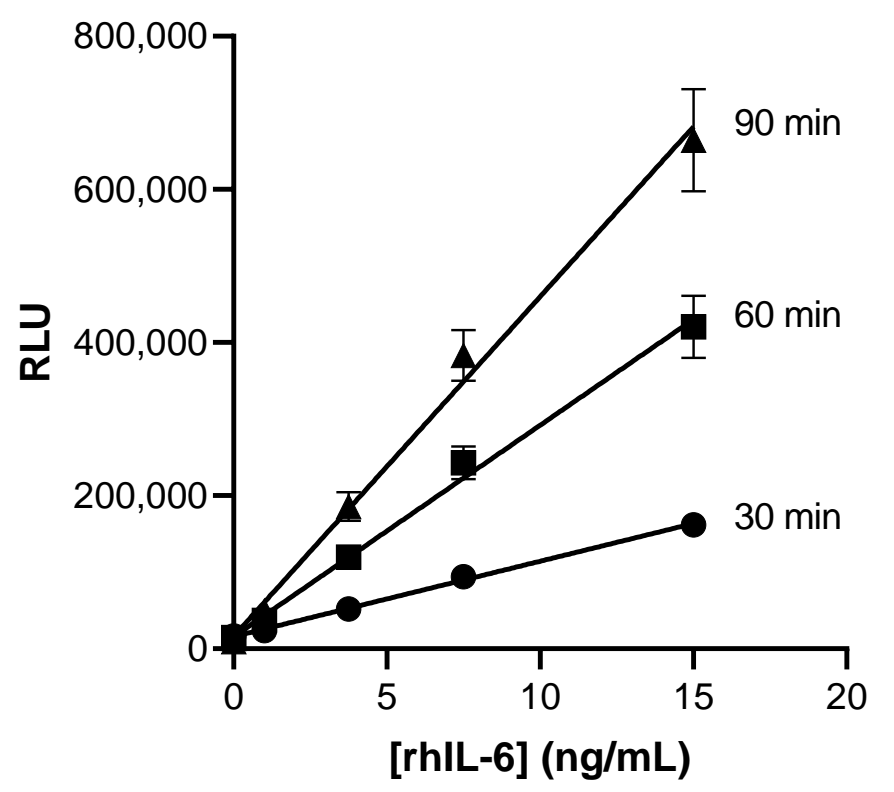

(b)

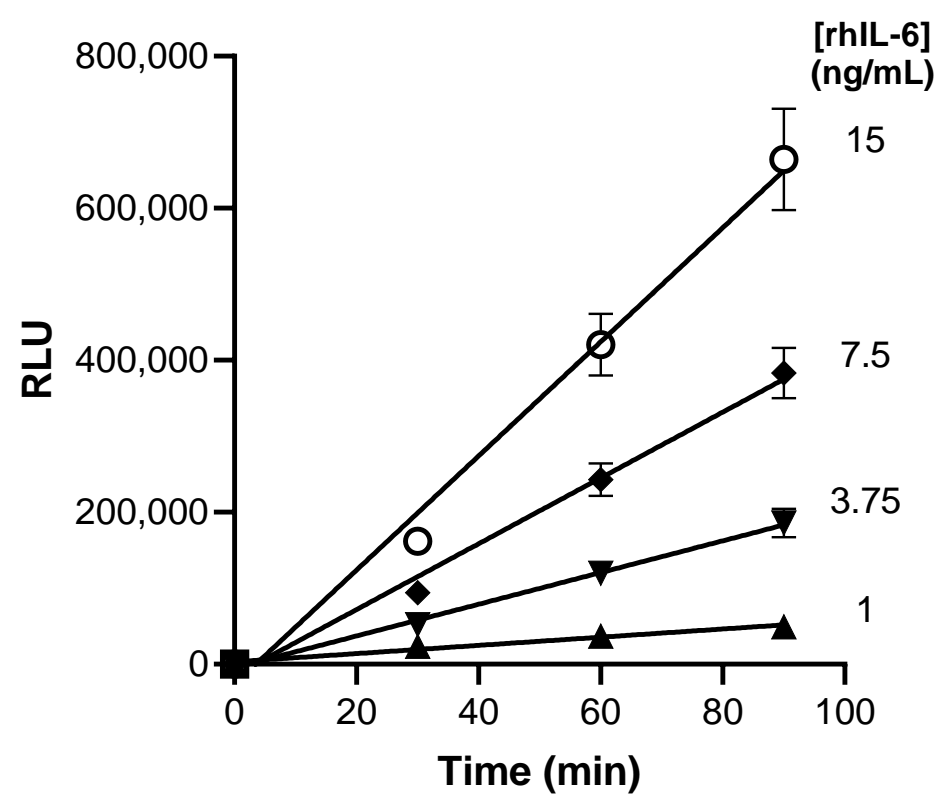

Figure S15. Lyo-based ternary Nluc IL-6 immunoassay kinetics. (a) [hrIL-6] dependent signal increase was linear up to $15 \mathrm{ng} / \mathrm{mL}$. Linearity was observed using three different time points: 30,60 , and $90 \mathrm{~min}$. (b) Same data in panel a plotted to show linear time course. Note this data is partially redundant with Figure $\mathrm{S} 14 \mathrm{a}$ ( $90 \mathrm{~min}, 15 \mathrm{ng} / \mathrm{mL}$ result). 